\title{
Inequality, poverty and the Kuznets curve in Spain, 1850-2000
}

\author{
LEANDRO PRADOS DE LA ESCOSURA \\ Universidad Carlos III de Madrid, Departamento de Historia Económica e \\ Instituciones and Instituto Figuerola, Calle Madrid I26, 28903 Getafe \\ (Madrid), Spain, leandro.prados.delaescosura@uczm.es
}

\begin{abstract}
Economic rather than political forces appear to dominate inequality trends in Spain. Inequality evolution fits a Kuznets curve. Wars increased inequality but had non-permanent effects, while progressive taxation had no impact until I980, at odds with Atkinson, Piketty, Saez and associates' findings. A substantial fall in absolute poverty resulted from growth but also from inequality reduction in the interwar period and the late I950s. Rising inequality and extreme poverty are not found at the roots of the Spanish Civil War. Between the mid I950s and 1974, inequality contraction and absolute poverty eradication represented a major departure from Latin America's performance while matching the OECD's.
\end{abstract}

\section{Introduction}

[S]peculation is an effective way of presenting a broad view of the field; and so long as it is recognized as a collection of hunches calling for further investigation rather than a set of fully tested conclusions, little harm and much good may result.

- Simon Kuznets (1955, p. 26)

This is an intentionally dry and descriptive article. Its goal is assessing long-run inequality and calibrating the joint impact of growth and inequality on absolute poverty. As a result, some explicit hypotheses are provided to stimulate historical research on income distribution and its links with poverty and social conflict. Modern Spain has been chosen as a case study as it represents a middle-size country that has been through complex circumstances: a long and painful transition to a liberal society during the nineteenth century, broken by revolutions and civil strife; a short and convulsive democratic experience, followed by a bloody civil war (19369) that gave way to a long-lasting autocracy under General Franco (I93975); and a successful combination of growth and openness in a democratic context during the last three decades. 
Table I. GDP, population, and per capita GDP growth, I850-2000 (annual average logarithmic rates)

\begin{tabular}{llll}
\hline \hline & GDP & Population & Per capita \\
\hline I850-2000 & 2.5 & 0.6 & I.9 \\
I850-I950 & I.4 & 0.6 & 0.8 \\
I95I-I974 & 6.5 & I.0 & 5.5 \\
I975-2000 & 3.0 & 0.4 & 2.6 \\
I850-I883 & I.8 & 0.4 & \\
I884-I920 & I.3 & 0.6 & I.4 \\
I92I-I929 & 3.8 & I.0 & 0.7 \\
I930-I952 & 0.8 & 0.9 & 2.8 \\
I953-I958 & 4.7 & 0.8 & 0.0 \\
I959-I974 & 6.9 & I.I & 3.9 \\
I975-I986 & 2.5 & 0.7 & 5.8 \\
I987-2000 & 3.5 & 0.2 & I.8 \\
\hline \hline
\end{tabular}

Note: Real GDP Divisia Index.

Sources: Computed from data in Prados de la Escosura (2003).

Since the mid nineteenth century modern economic growth has irreversibly proceeded in Spain. The steady increase in the aggregate economic activity represents, over a period of a century and a half, a multiplication coefficient of 43 , while population increased more than two and a half times. As a result, the product per head by 2000 was 16 times greater than in 1850 , which represents an average growth rate of $\mathrm{I} .9$ per cent per year (Table I). But how much of this sustained growth did percolate through to reach the lower quintiles of income distribution, or have an impact on absolute poverty reduction? These are the issues addressed in this article that consists of four sections. Direct income distribution estimates based on microeconomic evidence prior to 1973 are not available and, in its absence, an indirect macroeconomic approach to appraising inequality is introduced in Section 2, in which all the available information about inequality is collated to get an aggregate picture of its evolution since the mid nineteenth century. It turns out that the evolution of income inequality resembles a wide inverted W with peaks in I9I8 and I953. When the crude Gini coefficient is plotted against real per capita income a single Kuznets curve results. In Section 3 trends in inequality are confronted with different explanatory hypotheses. Economic rather than political forces have driven long-run trends in income distribution in Spain. World and civil wars increased inequality but lacked permanent effects, and progressive taxation had no impact until the I980s. These findings are at odds with the interpretation put forward by Atkinson, Piketty, Saez and their associates. Moreover, Stolper-Samuelson forces only partially explain inequality trends. In Section 4 an attempt is made at calibrating the impact of growth and inequality on absolute poverty. Economic growth, together with a decline in inequality, especially during the interwar years and since the I950s, led to a long-run reduction in 
absolute poverty. The fall in inequality and the eradication of absolute poverty between the mid I950s and early I970s represent major departures with respect to Latin America's patterns while matching those followed by OECD countries.

A research agenda for Spain's economic history emerges from the article's results. The Civil War (1936-9) occurred after one and a half decades of inequality decline and poverty alleviation, offering an interesting paradox that deserves further investigation. Furthermore, there was an inequality 'overshooting', possibly a consequence of the Civil War, during the early years of Franco's dictatorship, in which an association between isolation, sluggish growth and inequality resulted in high levels of absolute poverty. The late Francoist period appears as a benign phase of economic development in which structural change and capital deepening contributed significantly to inequality alleviation and suppression of absolute poverty.

\section{Inequality trends}

In the absence of direct estimates of income distribution for most of the last hundred and fifty years (household budget surveys are periodically available since 1964, but only fully exploited from 1973/4 onwards), an alternative approach has to be found. ${ }^{\mathrm{I}}$ Historical evidence on income distribution in Spain in the 'pre-statistical era' (that is, up to I973) is even less satisfactory than for present-day developing countries but, at the same time, social transfers represented a small proportion of GDP and the income tax was practically non-existent. ${ }^{2}$ Any attempt to provide orders of magnitude for personal income distribution over such a long time span is perhaps too audacious, but it could be justified in so far as it provides future researchers with hypotheses to be tested with new and more adequate sources.

The scattered and asymmetric (mostly post-I960) time coverage of conventional inequality datasets across countries has motivated attempts to overcome the lack of long-run data on income distribution by constructing alternative inequality measures on the basis of miscellaneous information (factor incomes, salary differences across professions, tax returns, and others). My approach is an eclectic one in which choosing between wage and salary dispersion and property income's share in total income is avoided and both are used to depict trends in aggregate inequality. ${ }^{3}$ Thus, the

${ }^{\text {I }}$ For a discussion of available household budget data and its treatment for the case of Spain, cf. Alcaide (1999) and Goerlich and Mas (200I, 2004). Alas, the microdata from the I964 household budget survey are currently missing.

${ }^{2}$ A similar picture is drawn for nineteenth-century France by Morrisson and Snyder (2000).

3 On such a dichotomy, cf. Williamson (I982) and Dumke (1988, I99I). I do not preclude, however, the possibility that changes in labour supply and unbalanced technological progress, as posited by Williamson and Lindert (I980), also play a role in inequality. 
association between the functional and the personal distribution of income is explored. ${ }^{4}$

I will consider the simplest case: that of two social groups, property owners and workers. In order to ascertain the evolution of income inequality we need to know the gap between the average incomes of the two groups and the dispersion of incomes within each of them. Classical economists stressed the breach between returns to proprietors and to workers. Their focus on the functional distribution of income was based on the implicit assumption that, as the overwhelming majority of workers were unskilled, the variance of labour incomes was very low. Later, as the economy developed and physical and human capital deepened, skilled workers increased their share within the labour force and, hence, the dispersion of labour returns rose (Kuznets I955). The stylized fact - and the hypothesis to be tested - is that, in the early stages of development, income inequality is driven by the gap between average returns of proprietors and workers and it is not until later, as economic progress takes place, that the dispersion of factor returns (labour, in particular) leads personal income distribution. If confirmed, this would help to explain why societies are more sensitive to different types of inequality over time. ${ }^{5}$

So, in order to establish long-run trends in personal income distribution we need to approach between- and within-group inequality, simultaneously. However, historians and social scientists tend to focus only on one of them at the time. Thus, while the top income shares approach, the Williamson index, and the labour share in national income are examples of betweengroup inequality measures, the skill premium, skilled-unskilled wage gaps and wage dispersion illustrate the emphasis on within-group inequality. Let me briefly examine some of these approaches in the Spanish case.

A major endeavour to derive yearly series of top income (and wealth) shares in national income for a growing sample of countries in the twentieth century is currently undertaken by Atkinson, Piketty, Saez and their associates on the basis of tax statistics. ${ }^{6}$ This appealing approach, rooted in Kuznets' (1953)

${ }^{4}$ Changes in the distribution of income between workers and proprietors should not be neglected if we want to keep the political dimension in the study of inequality. Dumke (I988), for example, stresses that given restricted franchise, income inequality implied political inequality in nineteenth-century Germany. This is also true of many other countries in Europe, including Spain (Cabrera and del Rey 2002, p. 72), where universal suffrage was only introduced in the late nineteenth or early twentieth century.

5 The tolerance to inequality probably differs over time, and social sensitivity to inequality within the middle or between the top and the bottom of the distribution varied across different epochs with subsequent political implications. In Spain, for example, prior to the Civil War (1936-9) intolerance of the rise in the share of top incomes was possibly greater than intolerance of inequality within wage earnings.

${ }^{6}$ The sample included initially OECD countries but has been widened to cover developing countries (India, Indonesia, Argentina). Cf. Atkinson and Piketty (2007) and Piketty and Saez (2006). There is a long-standing tradition of assessing inequality on the basis of the 
classical work, has, nonetheless, important shortcomings: only a very small fraction of the population was subjected to individual income taxation in many countries prior to the mid twentieth century, while fraud and tax evasion challenge the reliability of fiscal records as we move back in time or focus on countries with low-quality institutions. The historical case of Spain seems to fit this picture. High levels of fiscal evasion characterised the Spanish economy until the late twentieth century. Lack of political will to enforce taxation implied that no actual means (statistical records, bureaucracy) were available to fight evasion and fraud until the 1980s. ${ }^{7}$ In fact, income tax only became widespread since 1979, after a fiscal reform took place, and its share of total tax receipts went up from less than 2 per cent over the period 1940-78 to 30 per cent in the early 1980s (Comín 1996) ${ }^{8}$ Alvaredo and Saez (2007) have applied this approach to Spain since the early I930s. One of their main findings is that income concentration was much higher in the I930s than at the end of the twentieth century. Their figures for the top o.OI per cent income share show a dramatic decline between 1935 and I96I, especially marked throughout the I940s, and suggest stability between I96I and I98r. ${ }^{9}$ Top income shares increased in the last two decades of the twentieth century, as the joint outcome of top salary increases and capital gains. ${ }^{\text {IO }}$

An alternative to the top income share approach has been put forward by Jeffrey Williamson (I997), who proposes an 'inequality index' defined as the ratio between GDP per worker and the unskilled wage $(y / w u s)$, that has the advantage of being easily computable for most countries over long time spans. ${ }^{\text {II }}$ The rationale for $y / w u s$ is that while the numerator captures

shares of national income accruing to the top of the distribution (cf. Brenner, Kaelble and Thomas I99I) but only recently has such an approach been applied extensively and to a recent period.

7 Tax evasion was estimated in 40 per cent of tax receipts by the late I970s (Comín I996). Alvaredo and Saez (2007) claim that, among top income earners, fraud and evasion prior to I980 was much lower that usually assumed, and not significantly higher than in France and the US.

${ }^{8}$ In practice, in today's Spain income tax represents a tax on salaried incomes as 70 per cent of evasion occurs among high incomes (Comín 2006). The huge tax debt uncovered by tax inspection between 1979 and 1994 suggests a significant increase in the Government commitment to fight fiscal evasion (Pan-Montojo 2007).

9 Actually Alvaredo and Saez (2007) only have evidence for three single years (I96I, I97I, I98I) to compute top income shares over the period I962-80. Furthermore, a break in the income tax series impedes Alvaredo and Saez in carrying out a rigorous comparison with their inequality computations for I98I-2002.

Io The finding that increases in top income shares at the end of the twentieth century are associated with labour income concentration - top wage earners - is consistent with the results for the English-speaking countries obtained by Piketty, Saez and their associates.

II Ideally (and this is the way I have computed it), each component should be normalised by the number of hours worked and expressed in nominal terms, that is, nominal GDP per hour: nominal unskilled wage per hour. Using nominal instead of real GDP and wage 
returns to all factors of production, the denominator only encapsulates returns to raw labour, so it compares the middle to the bottom of the income distribution. Nonetheless, it is worth stressing that the proportion of unskilled workers within the labour force dwindles as societies develop and broad capital deepening takes place. In this scenario comparisons over time tend to be inconsistent and when measured by $y / w u s$ inequality tends to be exaggerated. A possible solution is to use, instead, the average returns to all labour $(w)$, including both skilled and unskilled workers, as the denominator in the inequality index. ${ }^{\mathrm{I2}}$ This alternative measure $(y / w)$ is equivalent to the inverse of the share of labour compensation in national income ${ }^{13}$ under the assumption that the return per head of self-employed workers matches the average compensation of employees in their corresponding industry. ${ }^{\mathrm{I}}$

As returns to unskilled workers represented most of labour compensation in national income until the second half of the twentieth century (Prados de la Escosura and Rosés 2007), it could be expected that inequality indices computed with either unskilled (y/wus) or average wages $(y / w)$ would hardly differ up to the I950s. Thereafter, as skilled labour increased its share in national income while capital deepening occurred, large disparities between these alternative indices can be anticipated. ${ }^{15}$ The two short-cut measures are confronted in Figure I and, as predicted, no major discrepancy between their trends is observed up to the mid I950s. ${ }^{16}$ Henceforth, as physical and human capital deepening took place, a gap between the two inequality indices steadily opened up in the late twentieth century. A sustained and

avoids the use of deflators that may follow different trends as their composition is rather different. A similar measure was already used for the US by Williamson and Lindert (I980).

${ }^{12}$ In such a case, the inequality index would be defined as the ratio, in nominal terms, of GDP per hour worked to average wage per hour.

${ }^{13}$ That is, the inverse of the labour share, $G D P / w E$, where $w$ is the average wage and $E$, total employment, equals $(y / w)$.

14 This assumption is made to compute factor shares in the case of Spain. As a referee rightly points out, wage earners were probably a smaller group than family operatives, but with this assumption the problem is solved. The functional distribution of income has been used to measure inequality trends in Britain during the Industrial Revolution (Allen 2005), for Germany over the period I850-I950 (Dumke I988, I99I), and for a sample of Western European countries in (mostly) the twentieth century (Flora I983). For a survey of the literature on factor shares in history, cf. Prados de la Escosura and Rosés (2003).

${ }^{15}$ An increase in income inequality between skilled and unskilled workers could be expected in the presence of capital-skill complementarity in production (Katz and Autor 1999).

${ }^{16}$ See the Appendix for a description of the sources and procedures used in their construction. It is worth noting that similar results are obtained by Dumke (I988: 20) for Germany, I850-I9I3. Dumke interpreted the fact that skilled and unskilled labour shares did move along as contrary to the view that human (and physical) capital is a substitute for unskilled labour. The Spanish experience suggests, however, that the parallel evolution of $y / w u s$ and $y / w$ is the outcome of the relatively small share of skilled labour in total labour force prior to I950. 


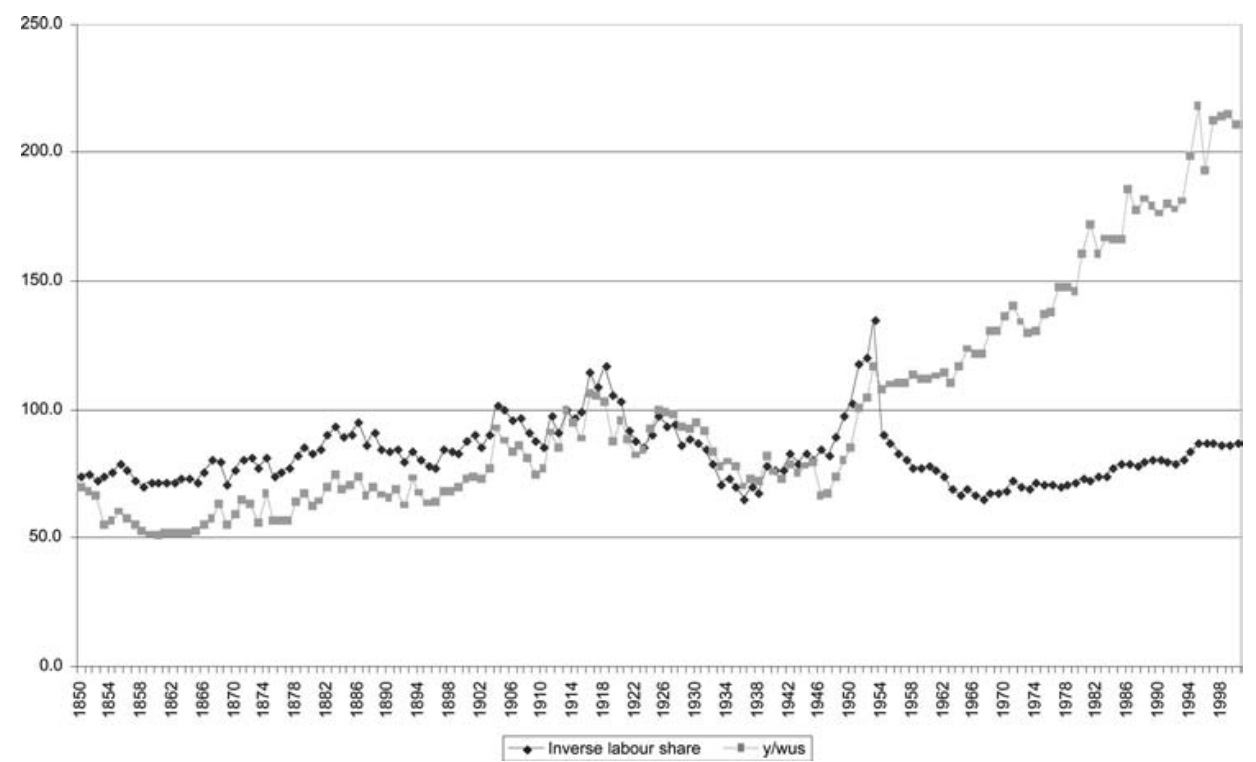

Figure I. Alternative inequality indices: the inverse labour share and the Williamson index $(y /$ wus $)(1913=I 00)$

dramatic increase was experienced by the Williamson index $(y / w u s)$ since I950; instead, a decline in $y / w$ occurred between the mid I950s and the mid I960s that gave way to a mild though steady rise during the rest of the century. Thus, as the share of unskilled labour in the workforce is sharply cut down, the significance of $y /$ wus as a measure of inequality fades away.

However, the share of labour compensation in national income provides a measure of inequality only in so far the dispersion within labour and property compensation does not change significantly. ${ }^{17}$ Ownership of capital (and land) has been highly concentrated in Spain (Martin 1990). ${ }^{18}$ If this were the case, a decline in the share of labour compensation in national income would indicate an increase in aggregate inequality. However, the assumption of stability in wage dispersion appears unrealistic as it tends to rise as the proportion of skilled workers within total employment increases (Kuznets I955). In fact, within-group inequality measures such as wage inequality or wage gaps are often used as a short-cut for the evolution of personal

${ }^{17}$ According to Piketty (2003), in many countries, long-run wage inequality has been very stable so trends in income inequality have depended on income distribution changes between property and labour.

${ }^{\text {I8 }} \mathrm{It}$ is worth mentioning that concentration of property has been often suggested but, to my knowledge, never tested with hard empirical evidence. A more uneven distribution of property than of labour incomes was suggested by Pigou (I920) (quoted by Dumke I988, p. I2). 


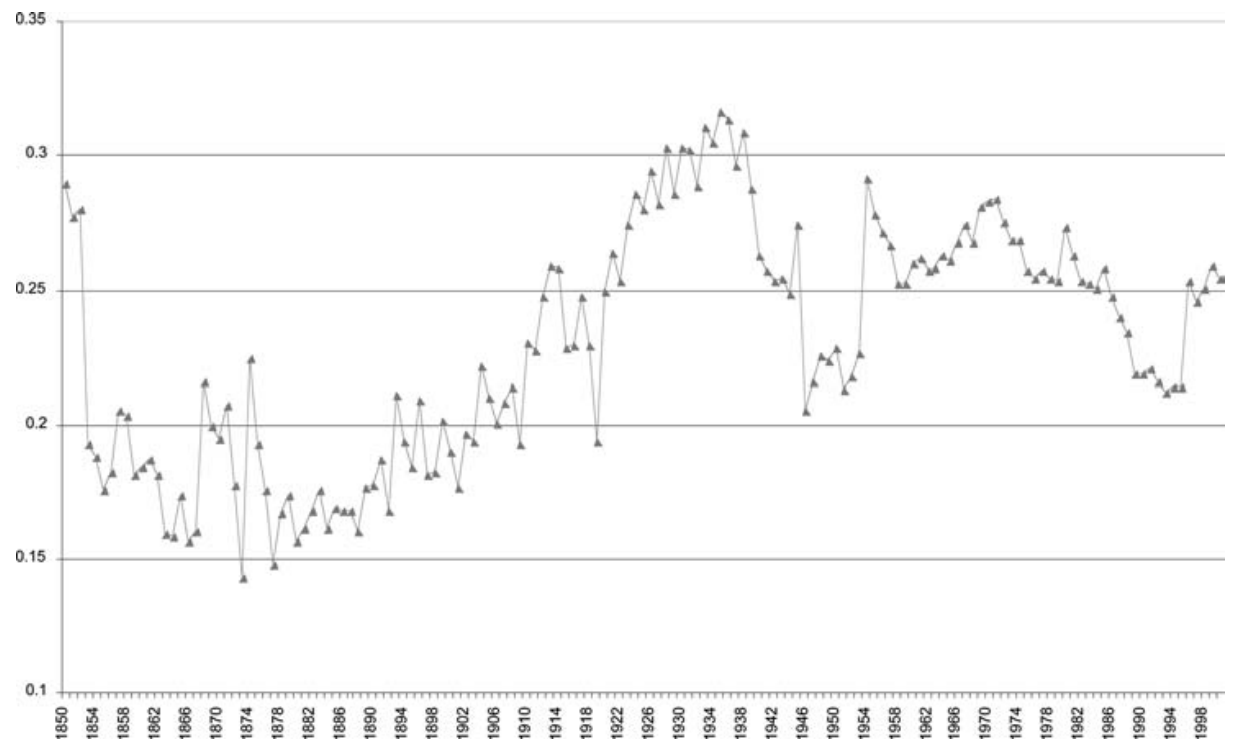

Figure 2. Wage Gini

income distribution. ${ }^{19}$ Figure 2 offers the Gini coefficient for wage earnings across industries (see the Appendix for its construction). If we compare the concentration of wages (Figure 2) with the inverse of the labour share in national income $(y / w)$ (Figure I), only a concurring rise in inequality from the mid I890s to World War I and a parallel decline between the mid I950s and the mid I960s appear. Otherwise, discrepancies prevail. In the interwar years, wage dispersion rises while $y / w$ falls. Conversely, between I970 and 1995, wage inequality falls whilst the inverse of the labour share in national income increases steadily. Thus, the bottom line of this examination of alternative inequality measures is that no conclusion can be reached about trends in total inequality unless its different components, the gap between property and labour returns and the dispersion within both property and labour, are taken on board.

Most inequality estimates for the post-I960 era use Lorenz curves and Gini coefficients. Moreover, the calibration of poverty headcounts (see the next section) usually requires Gini indices. Milanovic (2005, pp. 20-2) provides a decomposition of the Gini coefficient that facilitates the

19 Cf. Williamson (I982), and Williamson and Lindert (I980). It is also customary to rely on the gap between skilled and unskilled wages to draw wage inequality trends. Cf. Brenner, Kaelble and Thomas (I99I) and Morrisson and Snyder (2000). Wage gaps or skill premia and wage dispersion can, however, evolve in opposite directions, as the fall in wage inequality is not precluded by the rise in the skill premium as the proportion of skilled workers within the labour force increases. 
estimation of historical inequality on the basis of scattered and miscellaneous information. ${ }^{20}$ The Gini can be decomposed as follows:

$$
\text { Gini }=\sum G_{i} n_{i} \pi_{i}+\sum\left(\left(y_{p}-y_{l}\right) / y_{l}\right) \pi_{l} n_{p}+L
$$

Where the first part of the right hand term, $\sum G_{i} n_{i} \pi_{i}$ (Gini $A$, hereafter) is a weighted sum of within-group inequality - in our simplified case, inequality within labour and property returns. Each group $\left.{ }_{i}\right)$ is represented here by its own Gini coefficient $(G)$ and weighted by the group's shares in population $\left(n_{i}\right)$ and in national income $\left(\pi_{i}\right)$.

The dispersion of labour returns has been proxied by wage income inequality across industries over the period I850-2000. The Gini coefficient of average wage earnings across branches of economic activity has been computed. I was also able to estimate the Gini for wage earnings across industries in which four occupational categories were distinguished (unskilled, skilled operatives, technicians, and managers) for 1954-2000 (see the Appendix).

In the case of property incomes, lack of direct evidence led me to estimate its dispersion by alternatively assuming: (a) that it was high but constant over time, with an arbitrary value of 0.7 , more than twice as high as the peak for wage dispersion, 0.32 ; and (b) that it evolved like wage inequality but at a higher level. Since the highest wage inequality corresponds to I935, I allocated 0.7 to that year and moved it through time with the rate of variation of wage dispersion. Interestingly, the resulting values for Gini $A$ are practically identical under these alternative specifications (see Figure A-I in the Appendix), although I will focus on option (b), which, in my view, is a more plausible conjecture. ${ }^{2 \mathrm{I}}$

Then, it is necessary to determine the shares in national income and in population of those who get returns exclusively from either labour or property. National accounts distinguish between wages and salaries, property incomes and mixed incomes (those accruing from both labour and capital). The challenge here is, then, to establish which proportion of the income of the self-employed (including proprietors, unpaid family workers and retired workers) represents returns to labour. Colin Clark (1957) and

${ }^{20}$ I have carried out alternative inequality estimates, following Morrisson (2000), with decomposable entropy indices such as the Mean Logarithmic Deviation (MLD) or the Theil. The results obtained are highly coincidental with those derived from the Gini coefficient and are available from the author upon request.

${ }^{21}$ A sensitivity test for option (b) could be to compare wage dispersion with Alvaredo and Saez (2007) top income share in national income, as the latter could be seen as a proxy for property concentration, during the years I933-2000. It appears that both fell between I936 and the late I940s. Again, both measures are somewhat coincidental in the late I950s and, again, in the late I980s and early I990s. In other words, except for the late I940s and early I950s and most of the I980s their tendencies are coincidental. This result suggests that option (b) is a plausible one. 
Simon Kuznets (I966) favoured the approach of attributing to entrepreneurs and self-employed workers a labour income per head equal to employees' compensation per worker. I have assumed a return per head to non-wage labour identical to wage earners in the same industry (and, after 1954, within the same category) and derived the total income accruing to labour by dividing total wages and salaries by the share of wage earners in the labour force. Property income was obtained, then, as a residual by deducing labour income from GDP (see Appendix). ${ }^{22}$

The decomposition of the population between those receiving returns for their work and those whose income derives from property presents a further challenge. Alas, modern (post-1954) national accounts only distinguish between wage and non-wage earners in total employment. It is necessary, however, to split up the population into the 'equivalents' of those whose income exclusively accrues from property or from labour, avoiding any overlapping between the two groups. A crude and arbitrary procedure has been used. For the period 1954-2000, I first computed the proportion of property income in non-wage incomes (that is, total incomes accruing to property and to self-employment) and, then, applied this ratio to the share of non-wage earners in the total labour force in order to get a rough proportion of 'equivalent' property owners (that is, the share of population whose income comes exclusively from property). ${ }^{23}$ As for the hundred years before 1954, population censuses only provide figures of proprietors for three odd years: I860, I920 and I950, I interpolated exponentially the figures that correspond to each of these three benchmark years and the one for I954 to obtain crude annual series for property owners, and computed its proportion in total labour. Finally, I derived the share of the 'equivalent' population whose returns derived exclusively from labour as a residual for the entire time span 1850-2000. However, since it is commonly accepted that income from property was highly concentrated in Spain, it could be argued that the average proprietor was wealthier than the average person receiving nonwage income, and, that, consequently, my approach overstates the number of proprietors in Spain. In order to check this possibility I have computed an alternative Gini in which the share of property owners in the population was assumed to represent just one half of the previously estimated sum. As can be observed in Figure A-2 of the Appendix, these alternative results cast a slightly higher level of inequality but the same evolution over time.

The second element, $\sum\left(\left(y_{p}-y_{l}\right) / y_{l}\right) \pi_{l} n_{p}$ (Gini B, henceforth), corresponds to between-group inequality. Groups are ranked according to their mean income, so property owners $\left(y_{p}\right)$ always appear above those getting

22 Similar procedures were used by Hoffmann et al. (1965, pp. 506-9) and Matthews et al. (1982, pp. I64-72) for the cases of Germany and the United Kingdom, respectively.

${ }_{23}$ This implies the assumption that, on average, property owners and the self-employed had the same income. 
labour returns $\left(y_{l}\right)$ and their relative distance $\left(\left(y_{p}-y_{l}\right) / y_{l}\right)$ is weighted by the product of the labour returns' share in national income $\left(\pi_{l}\right)$ and the property owners' share in population $\left(n_{p}\right) .{ }^{24}$ Finally, $(L)$ is the overlapping component, or residual, and it accounts for the fact that someone who is a property owner may still have a lower income than someone getting labour returns. Since I cannot compute the overlapping $(L)$ directly, the following procedure has been used. If one makes the reasonable assumption that the lower the gap between returns per head to property and labour, the larger the relative importance of $(L)$, the problem is reduced to establishing its size. A possibility is to derive it as a residual by deducing the sum of Gini A and B estimates from direct computations of total Gini at benchmark years. Direct Gini estimates for Spain on the basis of microdata on household expenditure are available for 1973/4, I980/I, I990/I and 200I (Goerlich and Mas 200I, 2004)..$^{25}$ Thus, the value of $(L)$ derived for $1973 / 4$ was backwards projected to $\mathrm{I} 850$ with the ratio $\left(y_{l} / y_{p}\right)$ normalised for $\mathrm{I} 973 / 4=\mathrm{I}$. For the $\mathrm{I} 973-2000$ period, a single series was derived through a variable weighted geometric average from alternative estimates of $(L)$ which result from projecting each available Gini benchmark (I973/4, I980/I, I990/I, 200I) over time with the ratio $\left(y_{l} / y_{p}\right)$ normalised for each benchmark.

A sensitivity test has been carried out by computing the Gini coefficient making the distinction between wage and non-wage earners, rather than between labour and property income, for the period 1954-2000. The alternative results are highly concurrent (see Figure A-3 in the Appendix).

Trends in aggregate inequality, measured by the Gini coefficient and its components, Gini A and Gini B, are presented in Figure 3. Needless to say, they just represent a set of explicit hypotheses about income distribution in modern Spain. The evolution of inequality presents the shape of a wide inverted W with peaks in I9I8 and I953 that, perhaps, could be part of one big Kuznets curve broken by the Civil War and its autarchic aftermath.

Different long swings can be observed in the evolution of inequality. A long-term rise is noticeable during the early phase of globalisation that peaked by the end of World War I. The interwar period shows a sustained reduction in inequality cut short by the Civil War (1936-9) and sharply reversed during the autarchy years to peak in 1953. After a dramatic fall

${ }^{24}$ It should be kept in mind that, by construction, those who obtain returns from property (labour) do not receive any from labour (property). Average incomes of proprietors and workers have been obtained as follows: $y_{p}=\pi_{p} \mathrm{GDP} / n_{p} N$ and $y_{l}=\pi_{l} \mathrm{GDP} / n_{l} N$, where $N$ is total population (see Appendix).

${ }^{25}$ When several Gini estimates are available for a given benchmark year significant discrepancies tend to appear (Deininger and Squire I996; WIDER 2005) and procedures have been suggested to reconcile cross-section and time-series estimates (Atkinson and Brandolini 200I; François and Rojas-Romagosa 2005). Here I will only consider directly computed Gini on the basis of per capita expenditure microdata derived from household surveys by Goerlich and Mas (200I, 2004) from 1973/4 onwards. 


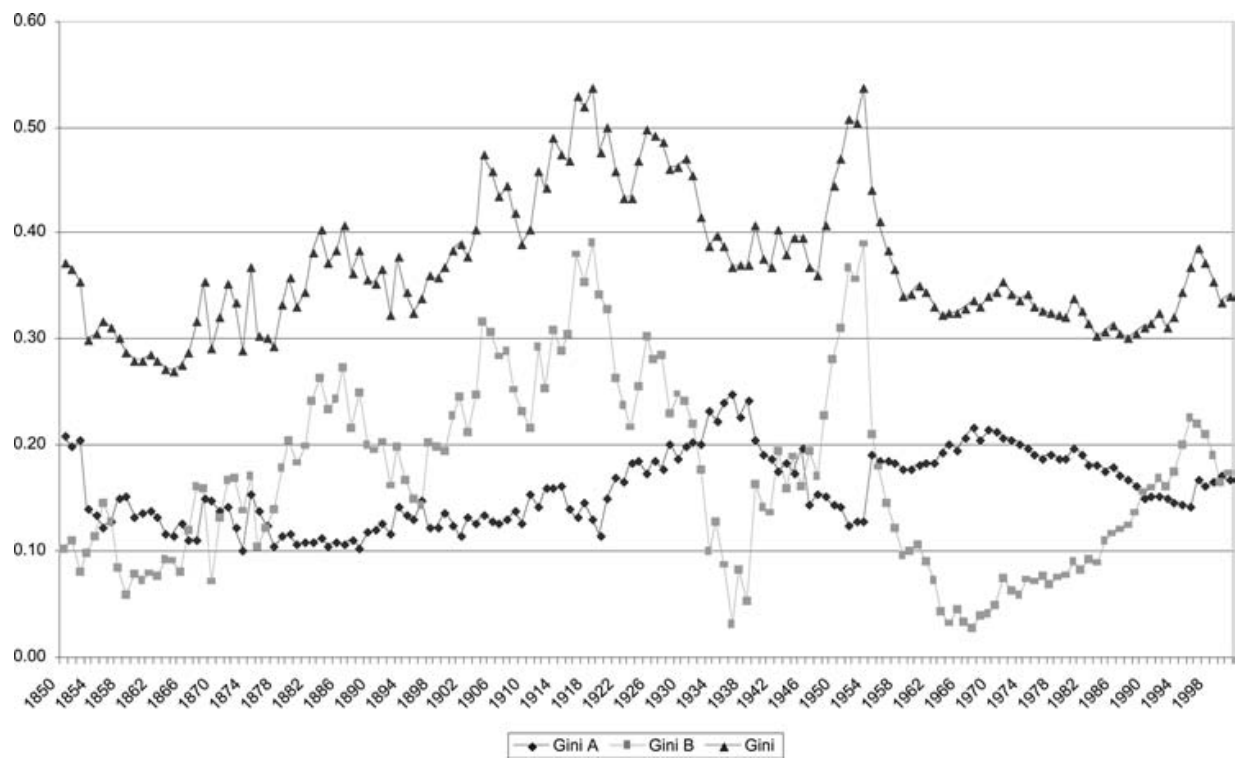

Figure 3. Gini and its components, 1850-2000

during the second half of the I950s, inequality exhibited a steady though mild reduction up to 1980 , to stabilise and then to rise again in the 1990 s. $^{26}$ The results for the late twentieth century are at odds with those derived from national accounts by Alcaide (I999), who finds a dramatic inequality contraction, after stability since the early I960s (Gini=42.I), during the early years of the transition from dictatorship to democracy, with Gini values falling from 44.6 in $1973 / 4$ to 36.3 for $1980 / 1 .{ }^{27}$

It is worth pointing out that the inequality trends described here are highly coincidental with those obtained from evidence on heights by Gloria Quiroga and Sebastián Coll (2000), who show a long-term increase in inequality among socio-professional groups between the turn of the century and World War I, a decline up to the eve of the Civil War, and a resumption of inequality during the autarchic I940s.

${ }^{26}$ Goerlich and Mas (200I, 2004) Gini estimates - the benchmarks used in my estimates correspond to household expenditures after income tax has been deducted and can, therefore, be considered post-fisc data. This means that if we had pre-fisc inequality estimates for the years after progressive taxation was introduced (from the 1980 os onwards), the resulting Gini would be higher than those provided by Goerlich and Mas and, therefore, the inequality decline since I 973 would be less marked and, conversely, the reduction in income inequality between the mid I950s and I970s relatively more acute.

${ }^{27}$ Jain (1975), in turn, provides a Gini of 38.8 for 1965. Other available estimates (Deininger and Squire I996; WIDER 2005; François and Rojas-Romagosa 2005) do not present significantly different results from those I have accepted from Goerlich and Mas (200I, 2004). 


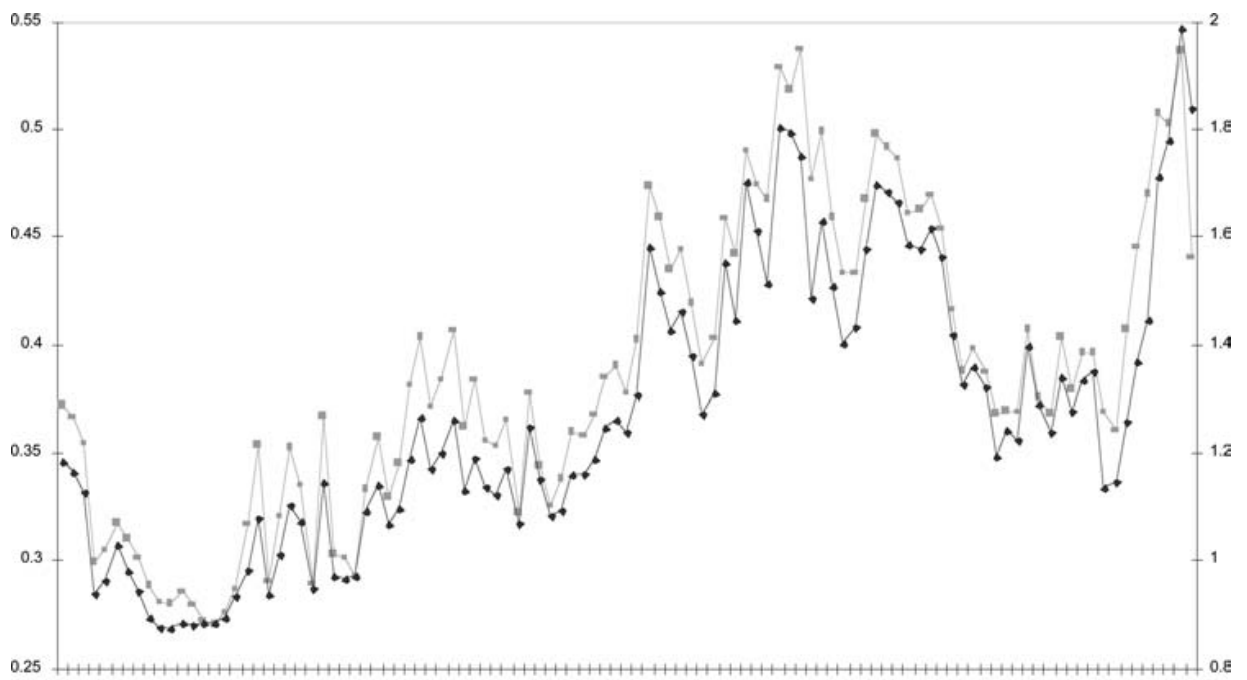

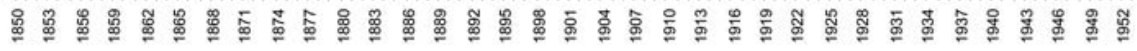

- Gini $\multimap$ yiwus

Figure 4. Gini and the Williamson index, I850-I954

Over the long run two distinctive phases emerge: during the first hundred years considered, Gini B, or between-group inequality, dominated personal income distribution. The reason is that, as unskilled labour represented the overwhelming majority of employment, the gap between property and labour returns drove aggregate inequality. Then, since the mid I950s, as the economy initiated a process of accelerated growth and structural change, skilled labour increased its share of employment and the dispersion of labour returns increased, and, hence, Gini A, or within-group inequality, became the main determinant of personal income distribution. Thus, the stylised fact about the long-run determinants of income distribution discussed above is confirmed for the case of Spain.

The fact that differences between returns to property and to labour dominated inequality trends during the first century of modern economic growth in Spain has some interesting implications for calibrating inequality in the absence of data. Figure 4 compares the evolution of the Gini estimates with the Williamson index (y/wus), and a close correlation is found over the period I850-I954. This result (in need of further confirmation for other countries) suggests that Williamson was right when he proposed $y / w u s$ as a short-cut measure of inequality for developing countries.

Does the evolution of personal income distribution fit a Kuznets curve? Recent historical literature has challenged this venerable hypothesis (Lindert 2000; Rossi et al. 200 I; Milanovic et al. 2007). In the case of Spain, inequality over time suggests an inverted $\mathrm{W}$ rather than the Kuznetsian inverted $\mathrm{U}$. It should be noted, however, that the Kuznets hypothesis associated the 


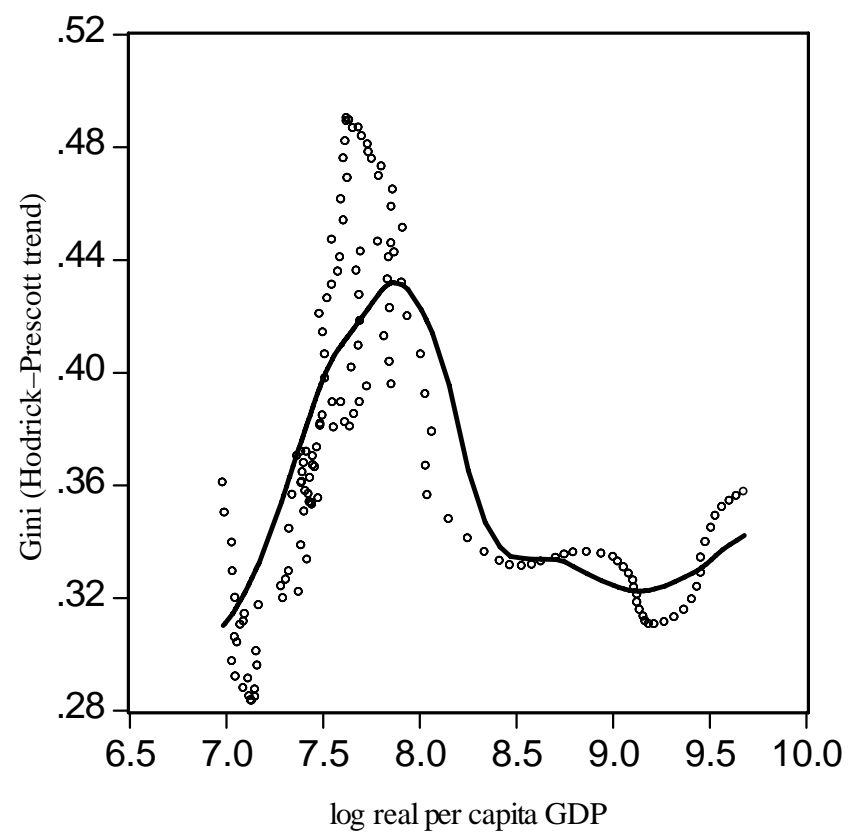

Figure 5. The Kuznets curve in Spain: kernel fit (Epanechnikov, $h=$ 0.4042 )

evolution of inequality with economic growth (Kuznets 1955). Thus, the relevant test would be to compare changes in the level of inequality to those in per capita income. Thus, in Figure 5, the Gini Hodrick-Prescott trend is plotted against the natural logarithm of real GDP per head, expressed in 1990 Geary-Khamis dollars to make it comparable internationally, and a single Kuznets curve emerges. ${ }^{28}$ The volatility of the upward side of the Kuznets curve can be observed. As an explanation it can be argued that, until the I950s, Spain was largely dependent on agriculture, a sector with very volatile output; this feature was reinforced by the fall of per capita income during the Civil War (I936-9) and its aftermath to pre-I920 levels, while simultaneously inequality increased. As Spanish growth accelerated since the mid I950s, rapidly reducing its dependence on agriculture, the downward side of the curve exhibits lower variability. Interestingly, the Kuznets curve appears to have been completed by the late I960s when inequality reached the low level around which it fluctuated during the late twentieth century.

${ }^{28}$ The log of per capita GDP and the Hodrick-Prescott filter for the Gini coefficient are introduced to highlight their relationship. The Hodrick-Prescott filter used a parameter $\lambda=$ Iо०. The Gini HP trend was plotted against the log of per capita income using a kernel fit Epanechnikov, with $\mathrm{h}=0.4042$. Real GDP series come from Prados de la Escosura (2003) and the benchmark level for I990 from Maddison (2003). 


\section{Inequality interpretations}

How can these inequality trends be interpreted? Different hypotheses have been put forward in the literature. External shocks and progressive income tax have been emphasised as major determinants of inequality trends by Piketty and Saez (2006). Specifically, the two World Wars and the Great Depression affected negatively the top income share in national income (in particular, capital income concentration), while progressive taxation did not allow its recovery. Significant changes, not always coincidental with those taking place in western Europe, occurred in Spain during the period I9I450. Moreover, the potential impact of progressive taxation was reduced by its delayed introduction in Spain (1979). ${ }^{29}$

World War I represented a major shock for Spain: relative prices changed so dramatically that they may have affected income distribution (Prados de la Escosura 2003; Rosés and Sánchez-Alonso 2004). The increase in inequality in Spain during World War I has also been found in other neutral countries (Denmark and the Netherlands) as profits rose due to increases in foreign demand and import substitution, while wages did not keep up with rising prices (Morrisson 2000, p. 249). This evolution is at odds with that of the belligerent countries during World War I. Moreover, the fall in income inequality resulting from 'destruction, inflation, bankruptcies, and fiscal shocks for financing wars' (Piketty and Saez 2006, p. 203) that occurred in France, Japan, or the US is missing after World War II in non-belligerent Spain, where the decline in inequality that followed the Great Depression was more than offset by the re-distribution of income towards property owners after the Civil War.

Alvaredo and Saez (2007) suggest a dramatic fall in top income shares inequality during the first two decades of Francoism. However, the behaviour of top income shares does not explain the evolution of total inequality in Spain in the post-World War II years (Figure 6). It could be argued that, in fact, the rise in total inequality was not determined by changes in the concentration of capital income - that would have fallen, according to the decline in top income shares (Alvaredo and Saez 2007) - but by an increase in the share of property income within total income. Thus, the distinction between Spain, where the Civil War had a divisive effect in the society, and most western countries, where the World Wars tended to increase social cohesion, may be relevant to understanding the post-war era.

How can we explain changes in the functional distribution of income? Christian Morrisson's (2000, p. 25I) remark that the institutional design historically guaranteed rents to proprietors but not to unskilled workers provides a clue. Tariff protectionism, for example, could be interpreted in

${ }^{29}$ It is worth mentioning that Piketty and Saez (2006) wondered about the fate of countries which experienced shocks but not progressive taxation. Actually, Spain provides a good example until I980. 


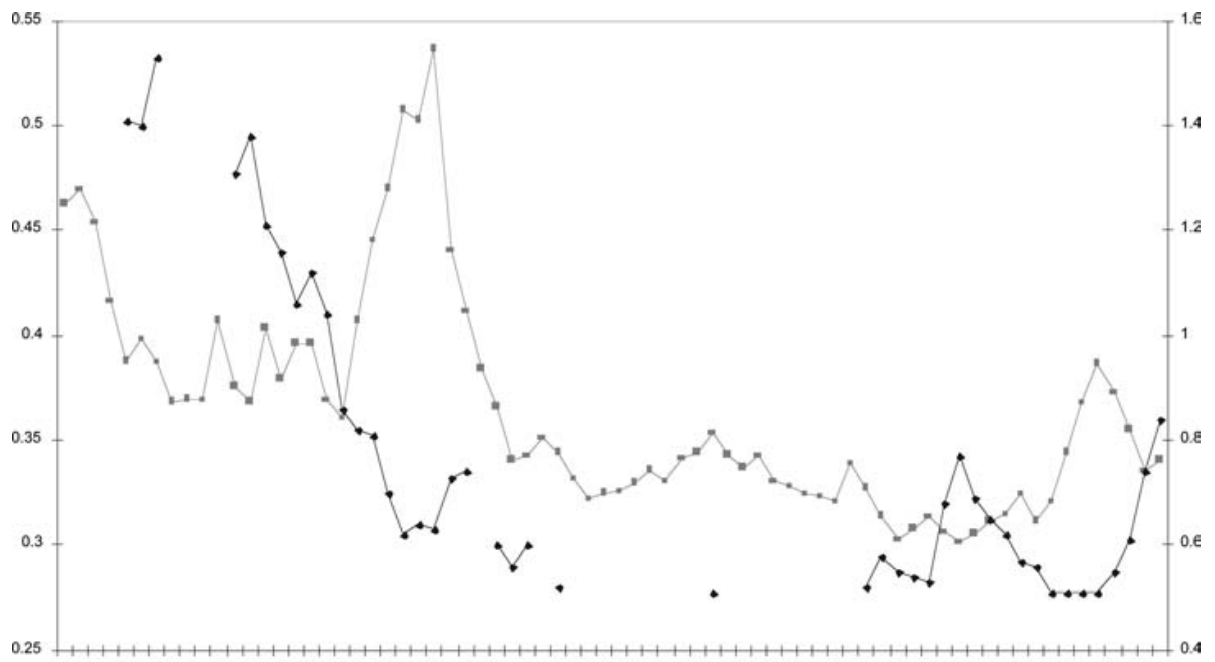

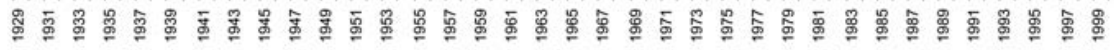

- Gini - Top Income Share $(0.01 \%)$

Figure 6. Gini and Alvaredo and Saez's (2007) top income share $(0.01 \%)$

this light and the Stolper-Samuelson model used, then, to provide explicit hypotheses about inequality trends (Williamson 2002). Does this model apply satisfactorily to the case of Spain?

The fall in inequality during phases of opening up to international competition (the late I850s and early I860s, the late I880s and early I890s), and the rise in inequality (from the late 1890 s to the end of World War I) coinciding with a return to strict protectionism, could be predicted within a Stolper-Samuelson (I94I) framework, which posits that protectionism favours the scarce factors (land and capital, in this case) while it penalises the abundant one (labour). In Spain, at the turn of the nineteenth century, Stolper-Samuelson forces would have been reinforced by the fact that tariff protection did not push out workers as in other protectionist European countries (i.e. Italy and Sweden). The depreciation of the peseta in the I 890 s and early I900s made the decision to migrate more difficult as the cost of passage increased dramatically (Sánchez-Alonso 2000, 2007). The Stolper-Samuelson model fails, however, to explain the rise in inequality between the mid I860s and early I880s. ${ }^{30}$

${ }^{30}$ Perhaps it was the outcome of a rise in capital and land returns relative to wages associated with the railway construction, and with the exploitation of mining resources after its liberalisation, and with the agricultural export boom (and exacerbated by French imports of wine after the phylloxera plague). 
The reduction in inequality during in the I920s and early I930s, a period of globalisation backlash, would not be consistent within a Stolper-Samuelson framework. ${ }^{3 \mathrm{I}}$ Other major forces conditioned the evolution of inequality. Accelerated growth, capital deepening, and structural change all helped reduce total inequality in the I920s. Wage inequality rose with rural-urban migration and urbanisation, given that urban wages were higher and with a larger variance than rural wages - as predicted in the Kuznets (I955) model - but the gap between returns from property and labour declined. ${ }^{32}$ Institutional reforms that included new social legislation, especially the reduction in the number of working hours per day, and the increasing voice of trade unions, contributed to a rise in wages relative to property incomes (Cabrera and del Rey 2002; Comín 2002).

The fall in inequality during the early I930s, with increasing restrictions to commodity and factor mobility, is, again, at odds with the view of Stolper and Samuelson. Forces pushing for redistribution were in place in Spain. On the whole, a reduction in the gap between returns to property and labour more than offset the rise in wage inequality. The Great Depression possibly had a negative impact on top income shares by reducing property income concentration, as Piketty and Saez would expect. ${ }^{33}$ Wages (nominal and real) certainly rose in a context of trade unions' increasing bargaining power and labour unrest. ${ }^{34}$ In the early I930s, new legislation that tended to increase labour costs, threats to land ownership, and attempts by workers to control factories created insecurity among proprietors leading to a severe investment collapse, and provoked a polarisation in Spanish society (Comín 2002, pp. 294-5; Cabrera and del Rey 2002, pp. 22I-35). 35

How could the evolution of inequality during the post-Civil War, autarchic years (1939-53) be interpreted? After the inequality reduction resulting from the war itself and from the pro-labour policies of the Second Republic,

${ }^{31}$ Conventionally, the I920s are depicted as years of intense isolation. However, this is no longer the prevailing view, as trade protectionism in this period was paralleled by substantial foreign capital inflows that broke the close link between investment and saving (Prados de la Escosura 2007c).

${ }^{32}$ On rural-urban wage gaps and migration, see Rosés and Sánchez-Alonso (2004) and Silvestre (2005). Urbanisation figures are provided in Tafunell (2005).

33 Alvaredo and Saez (2007) observe, however, an increase in top income shares for 1933-5. Was this a post-crash recovery?

34 The increase in the number of days lost due to strikes rocketed during the Second Republic, reaching 0.64 per cent of the days worked in 1933, a figure slightly above that of the peak year (I979) during the 'transition to democracy' ( 0.56 per cent). Estimates computed with days of strike are from Maluquer de Motes and Llonch (2005) and total days worked per year from Prados de la Escosura and Rosés (2007). On wage data see the Appendix.

35 Between I929 and 1936, gross domestic capital formation was cut by half in real terms (and to one-fourth in the case of investment in dwellings), while its share in nominal GDP fell from I6.9 in 1929 to II.9 in 1936 (Prados de la Escosura 2003). 
Franco's victory turned the balance away and, in doing so 'overshot' some 'normal' ratio between property and labour incomes. Wage compression took place as a result of the re-ruralisation of Spanish economy (the share of agriculture increased in both output and employment) and the ban on trade unions. Simultaneously, a parallel decline in the o.oI per cent top income shares during the I940s took place (Alvaredo and Saez 2007). Thus, while inequality was falling within both labour and capital returns, polarisation between property and labour caused a rise of total inequality. ${ }^{6}$ International isolation, resulting from autarchic policies would intensify these trends, with inequality rising as scarce factors, land and capital, were favoured at the expense of the abundant and more evenly distributed factor, labour.

A dramatic decline in inequality occurred during the mid and late I950s, that is, prior to the conventional phase of liberalisation and opening up that followed the I959 reforms (Prados de la Escosura and Sanz I996). It can be hypothesised that it was triggered by economic agents' increasing confidence in the viability of Franco's dictatorship after the US-Spanish cooperation agreements (Calvo-González 2007) that led to imports of new vintage equipment and to an increase in the investment rate. Between 1953 and 1958 a spurt of economic growth brought with it improvements in living standards (private consumption grew parallel to per capita GDP), urbanisation, and an increase in the labour share within national income (Prados de la Escosura 2007a). Furthermore, populist policies by Franco's Minister of Labour led to a substantial pay rise across the board in 1956 (Barciela 2002).

It appears, then, that not only international economy forces played a role in reducing inequality during the second half of the twentieth century. Growth and structural change played a non-negligible part. The rise in savings, helped by the financial development that went together with economic growth (Comín 2007; Martín Aceña and Pons 2005), facilitated access to housing ownership, which, in turn, helped reduce the concentration of property income. The diffusion of education (Núñez 2005) surely played a role in the decline of inequality by reducing the concentration of human capital. Furthermore, the decrease in regional disparities, conditioned by technological catch-up, the generalisation of basic education, and the spatial redistribution of employment (de la Fuente 2002), must have also impinged on income distribution. ${ }^{37}$

Perhaps the coincidence between the social policies of the late Francoism and the cautious opening up of the economy could be interpreted in terms

${ }^{36}$ On the concept of polarisation, see Esteban and Ray (I994).

37 In fact, the moderate decline in regional dispersion of per capita incomes during the early twentieth century reversed after the Civil War (1936-9) (Domínguez 2002), to resume its decline at a faster pace after the mid I950s, and then to stabilise during the last two decades of the twentieth century (Cuadrado Roura 1999). 
of an association between exposure to international trade and the weight of the government sector (Rodrik 1997). Even though the modern welfare state was not fully introduced in Spain until the transition to democracy, social expenditures had already increased in the late Franco period (I96075) and must have had an effect on reducing inequality. The share of social expenditure in GDP (excluding education) went up from 5.9 to I2.5 per cent in the last decade of Francoism representing a partial catching up with western Europe's share (Bandrés I999).

Increasing political participation after democracy was reinstated in I977 led to a progressive fiscal reform and to substantial increases in public expenditure on social transfers (unemployment, pensions), education and health that had a strong redistributive impact and triggered a further inequality reduction (Gimeno Ullastres I999). The share of social expenditure in GDP reached I9.6 per cent in I98I and peaked in 1993 (26.7 per cent) (Bandrés 1999). Public expenditure on welfare (including education) almost doubled its share in GDP during the first two decades of democracy. Political decentralisation of spending decisions also had an impact on the inequality decline (Goerlich and Mas 2004).

How does the case of Spain compare to other historical experiences? Estimates for aggregate income inequality over the long run are only available for a few OECD countries (Flora I983; Kaelble and Thomas I99I; Morrisson 2000)..$^{38}$ Denmark, Norway, Italy and the UK have Gini estimates going back to the late nineteenth century, as do Japan and the US outside Europe. Some crude historical estimates of inequality for Latin America are also available (Prados de la Escosura 2007b). There are, however, problems of comparability among Gini estimates constructed using different kinds of data that have led analysts to focus on trends rather than on levels (Gottschalk and Smeeding 2000, p. 285). Hence, the historical evidence on Gini estimates I am presenting for a handful of countries should be taken with a grain of salt. Figure 7 indicates that Spain matched the behaviour of OECD countries except for the autarchic period that followed the Civil War. ${ }^{39}$ Interestingly, the comparison with Italy in the twentieth century depicts the latter as a case of more benign development. The contrast with the case of Latin America is illuminating (Figure 8$) .4^{\circ}$ Contrary to the usual assumption of

${ }^{38}$ Without taking into account the massive work produced by Atkinson, Piketty, Saez and their associates, as they concentrate on top income shares.

39 Data on Gini coefficients for OECD countries come from WIDER and Deininger and Squire (I996, updated) completed with Flora (I983) and Morrisson (2000) for Denmark and Norway; Rossi, Toniolo and Vecchi (200I) for Italy; Lindert (2000) for the USA; Lindert (2000) and Williamson (1985) adjusted to Lindert's revision (http://www.econ.ucdavis.edu/faculty/fzlinder/MassieI759rev.htm) for the UK.

40 The number after LatAm represent the countries included in different samples of Latin American countries. Thus, LatAm4 includes Argentina, Brazil, Chile and Uruguay; LatAm6, LatAm4 plus Colombia and Mexico; LatAmI5, all Latin American countries but 


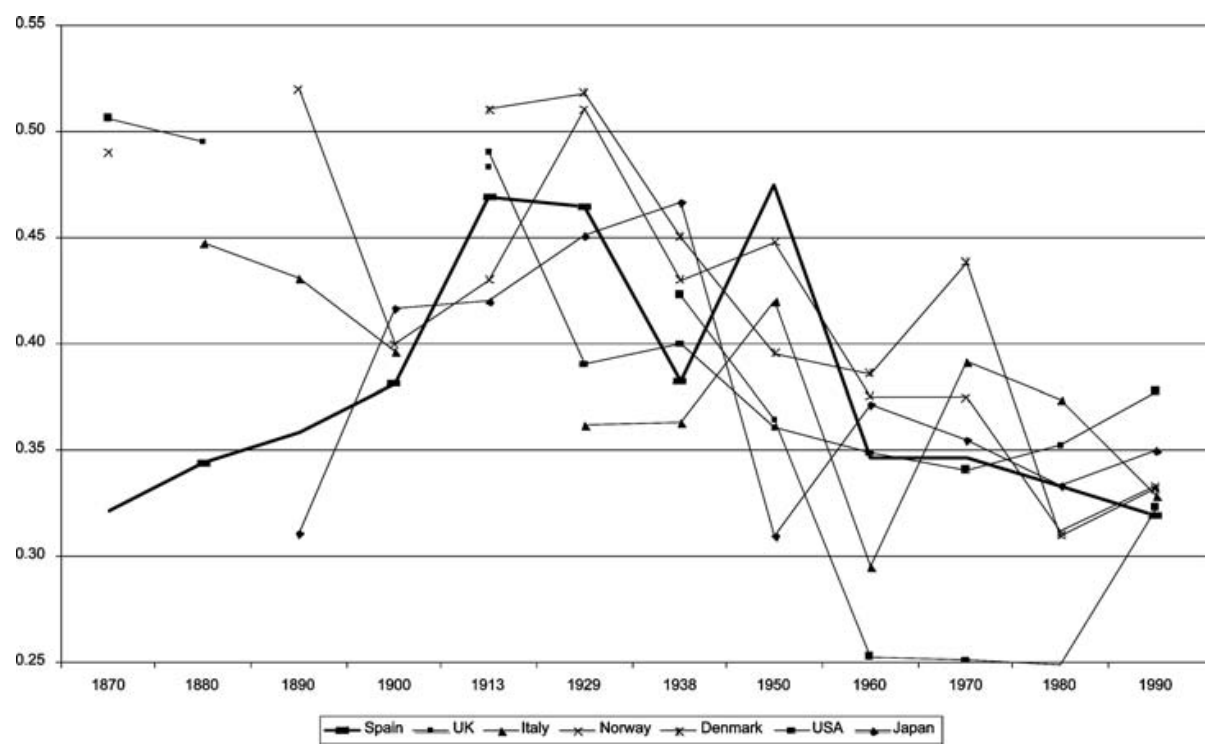

Figure 7. Gini in Spain and OECD countries, I870-2000

high and enduring inequality in Latin America since the colonial times, an upward trend up to the I960s brought inequality to the high plateau where it stabilised for the rest of the twentieth century. Spain and Latin America followed similar patterns until the mid I950s, when Spain shifted away to converge towards OECD inequality levels.

\section{Trends in absolute poverty}

How do trends in inequality and economic growth impinge on poverty reduction over the last century and a half? In this section I will calibrate trends in absolute poverty from which hypotheses for further research could be derived.

I will focus on the absolute growth of the incomes of the poor (Ravaillon and Chen 2003) rather than on whether they experienced a relatively disproportionate growth (Kakwani and Pernia 2000) and, therefore, the evolution of absolute poverty will be defined with reference to a fixed international poverty line.

If a fixed poverty line (PL) is conventionally defined at $\$ 2$ (expressed in 1985 purchasing power adjusted international dollars) per person and day, it was not until 1900 that average incomes (as measured by per capita GDP) doubled the poverty line in Spain. If we bear in mind the results from

Bolivia, Cuba, Haiti, Nicaragua and Paraguay; and LatAmI6, LatAmI5 plus Nicaragua. See Prados de la Escosura (2007b). 


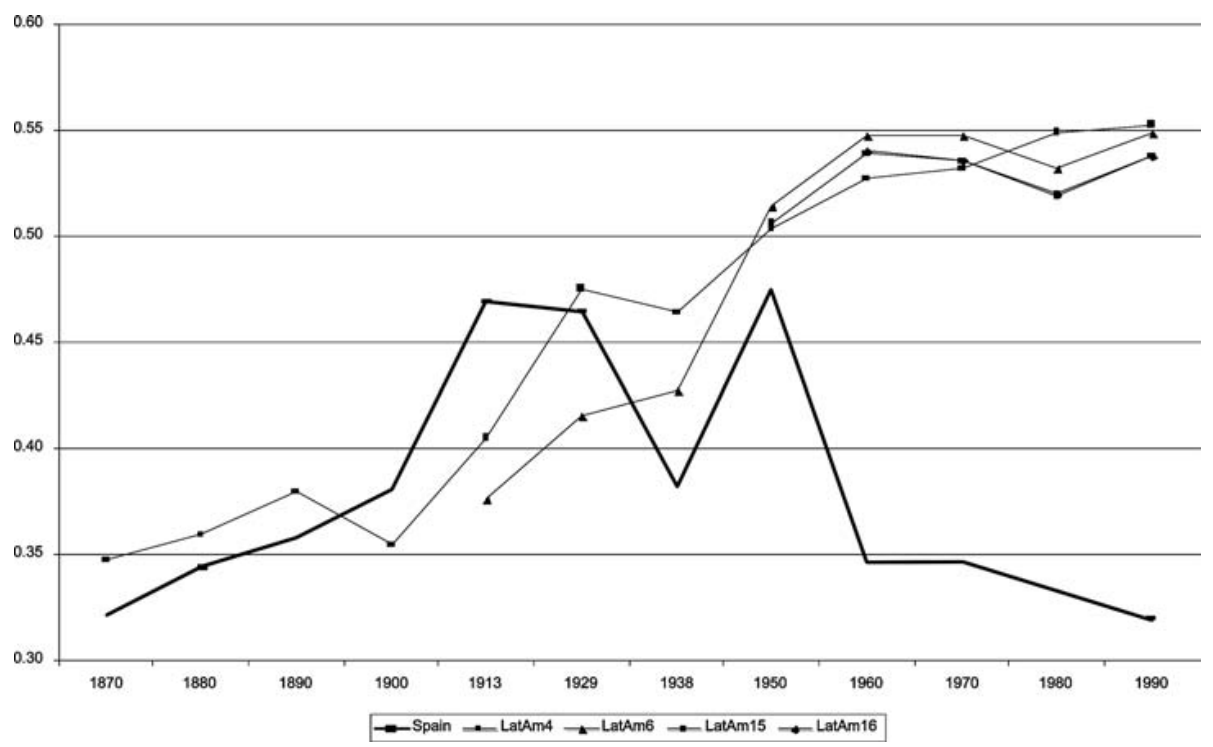

Figure 8. Gini in Spain and Latin America, I870-2000

recent empirical research in developing countries (for example, Bourguignon 2002; Klasen 2004; López 2004; Ravallion 1997, 2004), such a low level of development probably hampered the impact of growth on poverty reduction (Deininger and Squire 1998). In the ongoing debate on pro-poor growth few views are shared. One of them is that the higher the initial level of inequality, the lower the reduction in poverty for a given rate of growth in GDP per head. Thus, poverty reduction would depend on the initial level of average income and its subsequent growth, on the initial income distribution and its evolution over time, and on how sensitive poverty is to growth and inequality changes (Bourguignon 2002; Ravaillon 2004; López and Servén 2006).

How much impact would average income growth and distribution changes have had, then, on absolute poverty in the case of Spain? During the nineteenth century and up to World War I low per capita income and increasing inequality may have drastically reduced the impact of economic growth on poverty. High initial inequality would also have mitigated the effect on poverty of the acceleration in economic activity during the I920s, as would have been the case during the $1953-8$ recovery in growth. Moreover, faltering growth in the early I930s presupposes that falling inequality had a weak effect on poverty reduction. The unprecedented growth of the years 1959-74 suggests, however, that once the low initial income constraint has been removed, the impact on poverty would be noticeable.

Can these hypotheses be put to the test? Unfortunately, no microeconomic data are available on Spain's household expenditures to compute poverty levels and trends before the late twentieth century. In these circumstances, 
Bourguignon and Morrisson's (2002) assumption that income distribution remained unaltered in Spain from the early nineteenth to the mid twentieth century appears very appealing. In such a case, it would suffice to know the growth rate of GDP per head to assess the evolution of absolute poverty over time. In fact, recent research indicates that a large proportion of long-run changes in poverty are accounted for by the growth in average incomes (Kraay 2006), and, hence, emphasises the protection of property rights, stable macroeconomic policies and openness to international trade as simultaneous means to achieve growth and suppress absolute poverty (Klasen 2004; OECD 2004). Assuming a one-for-one reduction in poverty with per capita GDP growth seems, however, a gross misrepresentation ${ }^{4}$ and, thus, I have preferred to rely on the macroeconomic evidence on growth and changes in income distribution presented in the two previous sections to propose conjectures about historical trends in absolute poverty.

I have calibrated the impact of growth and inequality changes on absolute poverty for the case of Spain on the basis of López and Servén's (2006) recent empirical research that expands previous research by Bourguignon (2002), Ravallion (1997, 2004) and Kraay (2006) and draws on the largest micro database available so far, for a wide sample of developing and developed countries over the last four decades. Using a parametric approach, López and Servén (2006) find that the observed distribution of income is consistent with the hypothesis of log-normality. Under log-normality, the contribution of growth and inequality changes to poverty reduction only depends on the poverty line/average incomes ratio, and on a measure of inequality (the Gini coefficient). The poverty headcount, $\mathrm{P}_{\mathrm{o}}$, that is, the share of population below the poverty line, is derived as,

$$
\begin{aligned}
& \mathrm{P}_{\mathrm{o}}=\Phi(\log (z / v) / \sigma+\sigma / 2), \\
& \text { Where } \sigma=\sqrt{2} \Phi^{-\mathrm{I}}((\mathrm{I}+\mathrm{G}) / 2)
\end{aligned}
$$

in which $\boldsymbol{\Phi}$, is a cumulative normal distribution; $\boldsymbol{v}$, the average per capita income; $\boldsymbol{z}$, the poverty line; $\sigma$, the standard deviation of the distribution; and $\boldsymbol{G}$, the Gini coefficient.

Thus, all I need to calibrate the poverty headcount is the poverty line/average income ratio and the Gini coefficient (for which I will use the crude approximation derived in Section $\mathrm{I}$ ).

A long-run decline in absolute poverty is the main feature of the evidence presented in Figure 9. Poverty reduction occurred, nonetheless, at different speeds over time - a result that supports the view that the impact of growth on poverty is weakened in the presence of rising inequality and low initial

${ }^{41}$ Ravallion (2004) has proposed to associate poverty changes to economic growth using the expression: Rate of poverty reduction $=\left[\text { Constant }{ }^{*}(I-\text { Inequality index })^{\theta}\right]^{*}$ growth rate. In which the constant is negative ( -9.3 in Ravaillon's example) and the aversion coefficient $\theta$ is not less than one (Ravaillon suggests $\theta=3$ ). 


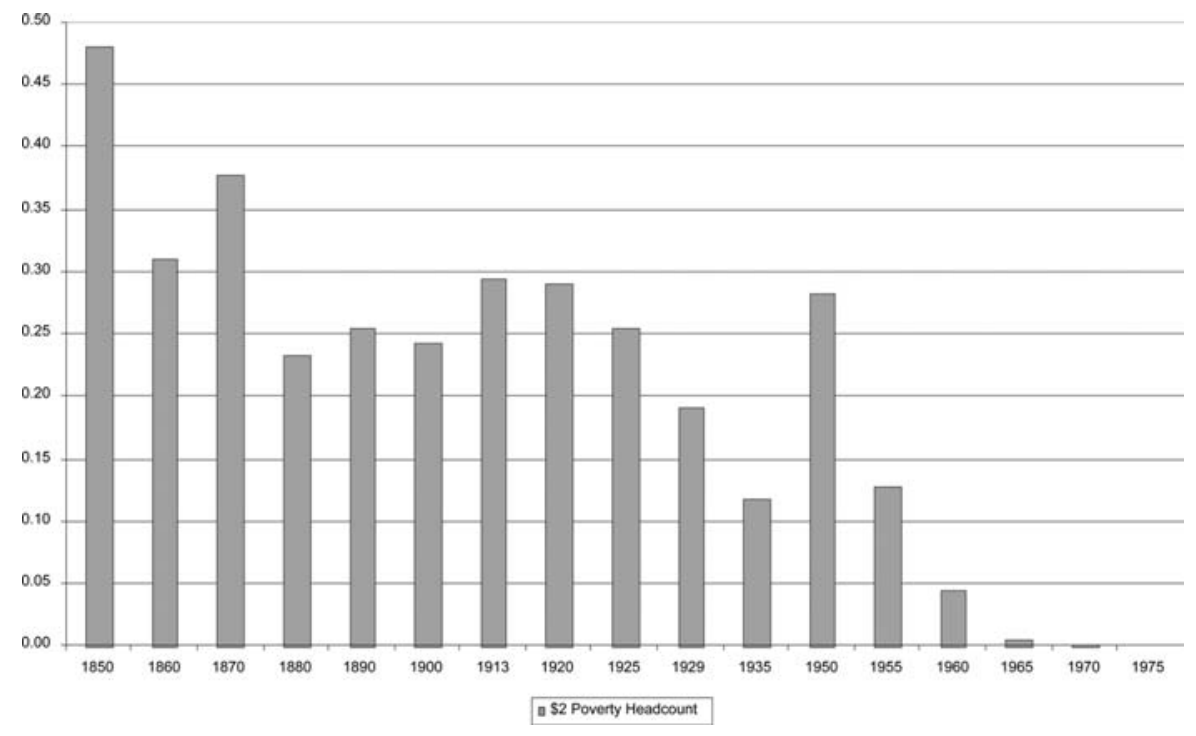

Figure 9. Poverty headcount (poverty line: 1985 Geary-Khamis $\$ 2$ a day per person)

levels of development - while once the initial income constraint is released, its effect heightens (Table 2, col. I). A major contraction took place between I850 and I880 that stabilised, and then reverted its trend to peak during World War I. Growth underlies the fall in absolute poverty over the third quarter of the nineteenth century as inequality did not change substantially. Sluggish growth and rising inequality explain the increase in absolute poverty during the period I880-I920. The sharp decline in absolute poverty during the interwar years was the combined outcome of a sustained fall in inequality and the fast growth of the I920s. This constitutes a counterintuitive result, as an association between staggering inequality and extreme poverty and the break up of the Civil War has been hinted, though never proved, in the literature (cf. Pérez Ledesma 1990 and Payne 1993). During the early years of Francoism (1939-53), rising inequality and poor economic performance brought the share of those below the poverty line to pre-I920 levels. Conversely, the late period of Franco's dictatorship appears as a benevolent epoch of falling inequality and increasing per capita income, which jointly eradicated absolute poverty by the mid I960s.

A glance at Figure 3 might suggest, however, that given the similar level of inequality in the mid nineteenth and late twentieth centuries, growth by itself would explain the eradication of absolute poverty. Was this the case? In order to reckon the impact of growth on poverty reduction, I have carried out a counterfactual exercise in which I computed the poverty headcount under the assumption that inequality remained unchanged at a high level (that of 1950) throughout the period 1850-2000. The results for the calibrated and the counterfactual poverty headcounts are offered in Figure Io, while 
Table 2. Absolute poverty headcount: actual and counterfactual rates of decline (\%)

\begin{tabular}{lcc}
\hline \hline & Actual & Counterfactual \\
\hline I850-I880 & 2.4 & $\mathrm{I} .2$ \\
I880-I920 & -0.5 & 0.8 \\
I920-I935 & 5.9 & $\mathrm{I} .7$ \\
I950-I960 & $\mathrm{I} 8.2$ & 5.2 \\
I960-I975 & 32.8 & $\mathrm{I} 4.4$ \\
I850-I920 & 0.7 & $\mathrm{I} .0$ \\
I950-I975 & 27.0 & $\mathrm{I} 0.7$ \\
I850-I975 & 5.8 & 2.7 \\
\hline \hline
\end{tabular}

Sources: The counterfactual poverty headcount has been computed assuming constant inequality at the I950 level.

See text.

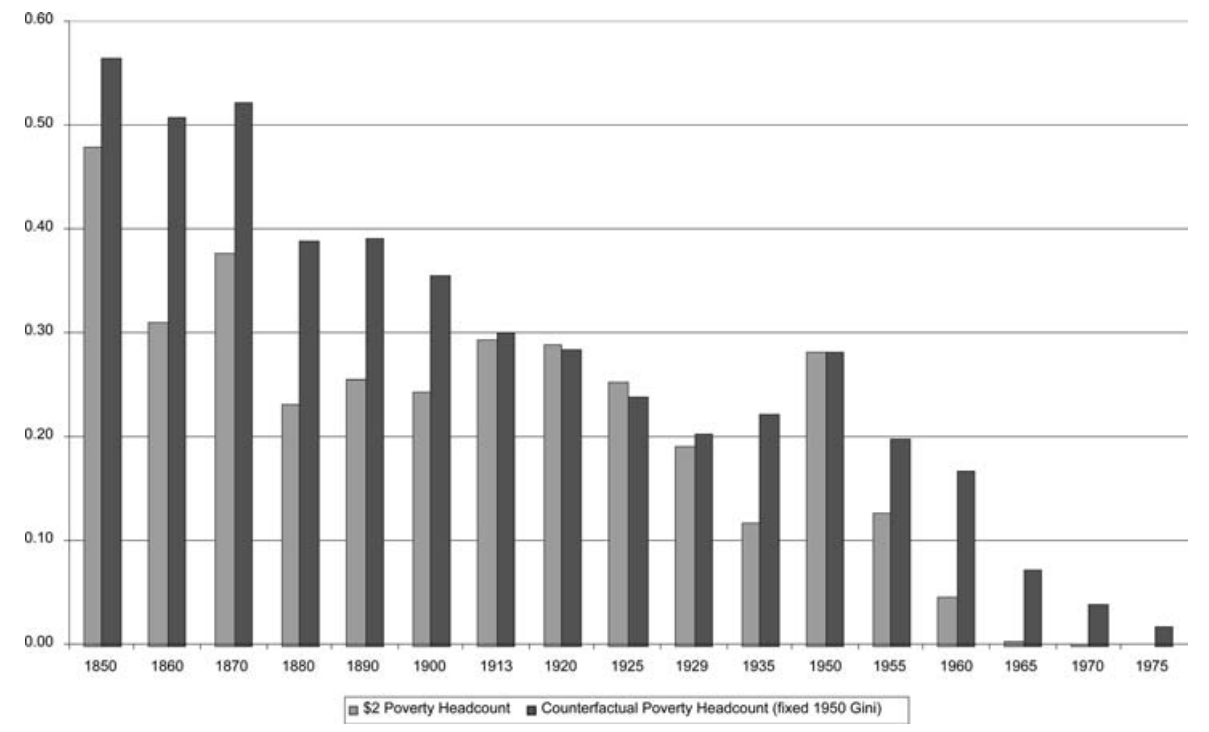

Figure Io. Actual and counterfactual poverty headcount (poverty line I985 Geary-Khamis $\$ 2$ a day per person)

the respective rates of poverty reduction are offered in Table 2. It turns out that although economic growth was the main force behind the long-run fall in absolute poverty, during some episodes of intense poverty decline a significant contribution came from the rapid decline in inequality (such as the late I920s to early I930s, and the late I950s).

The case of Spain presents interesting analogies with and differences from Latin America. Spain shadowed the evolution of Latin American poverty until the I950s, when inequality levels in Spain departed from those prevailing in Latin America and initiated a fast convergence towards OECD 
patterns..$^{42}$ Thus, the growth of per capita income had a higher payoff in terms of absolute poverty suppression in Spain than in Latin America, where the poverty headcount remained still high by the end of the twentieth century. 43

Alas, the controlled conjectures about absolute poverty behaviour in Spain over the long run cannot be confronted with hard empirical evidence except for the late twentieth century. The inequality reduction since the late I970s was accompanied by an expansion in average expenditure during the I980s. As a result, welfare increased, in real terms, between 37 and 5I per cent during I973-9I (Ruiz-Castillo and Sastre 1999). Using a fixed poverty line equivalent to 50 per cent of average expenditure in 1973/4 - del Río and RuizCastillo (I999, pp. 439-40) show a significant decline in the proportion of the poor for the late twentieth century: the absolute poverty headcount fell in per capita expenditure terms - from 22.2 per cent of the population in I $973 / 4$ to I5.I per cent in I980/I, and to 5.I per cent in I990/I. Thus, the trends derived from the historical calibration of absolute poverty are not at odds with the findings of empirical studies on the basis of microdata.

\section{Concluding remarks}

In Spain inequality rose during the late nineteenth century and up to World War I, reversed during the interwar years, witnessed an upsurge in the post-Civil War autarchy, and fell from the mid I950s until the I980s. During the first hundred years considered, the gap between property and labour returns drove aggregate inequality. Then, from the mid I950s, as growth and structural change accelerated, skilled labour increased its share of employment and the dispersion of labour returns became the main determinant of personal income distribution.

The contrast between Spain and Latin America offers a parallel longrun evolution up to the mid twentieth century when Spain deviated to converge towards OECD levels. However, Spanish inequality diverges from the western European pattern - at least, if one accepts the picture recently drawn by Atkinson, Piketty, Saez and their associates - as it fits a Kuznets curve, the two World Wars and Civil War increased it (although they did

${ }^{42}$ I have carried out a provisional calibration, similar to the one I did for Spain, for the sample of OECD countries included in Figure 7, which suggests that absolute poverty had been suppressed (that is, it represented less than I per cent of the population) in the US, the UK, Denmark and Norway by 1950, and in Italy and Japan by 1960 and 1965 , respectively (the latter the same date as for Spain).

43 According to my calculations using the same approach, those living on I $985 \$ 2$ or less by I990 represented 17 per cent of the population in Colombia, I5 per cent in Brazil and I I per cent in Chile; numbers had only been reduced to zero in Uruguay. Meanwhile the poverty headcount ranged between one-third and half the population in most of Central America and Bolivia. My estimates are significantly lower, though, than Székely's (200I) direct computations. 
not have permanent effects) and progressive taxation has only had an impact since 1980 .

In modern Spain no trade-off between inequality and growth is observed. In its most dynamic phases, inequality declined (the I920s, the Golden Age) but also increased (1850-83), while in years of sluggish performance, inequality deepened (I880s-I920, the post-Civil War autarchy) though it shrank too (during the Second Republic, I93I-6, and the transition to democracy, 1976-85). Furthermore, economic growth and declining inequality had dramatically different outcomes during the world crisis of the I930s and I970s: political and social strife leading to civil war in the former, democratic stability and social consensus in the latter.

Absolute poverty experienced a long-run decline. Growth prevailed over falling inequality as the main cause of poverty reduction, but a more egalitarian income distribution played a non-negligible part in crucial phases of absolute poverty decline. The contrast with Latin America reveals that thanks to a lower degree of initial inequality, Spanish economic growth in the late twentieth century had a much larger payoff in terms of absolute poverty alleviation.

From this preliminary assessment of modern Spain's experience, some hypotheses about the connections between growth, inequality and social conflict emerge. Attempts to introduce institutional and social reforms during the Second Republic (I93I-6) were accompanied by increasing social turmoil and political unrest that led to General Franco's uprising and to the Civil War (1936-9). Were there economic causes of the War of Spain? Was there a war of attrition on income and wealth distribution at the roots of the Spanish Civil War (Boix 2004)? The fact that it broke off after one and a half decades of inequality decline and poverty alleviation demands new explanatory hypotheses. Unfulfilled expectations to share increases in wealth by those at the bottom of the distribution may contribute, perhaps, to explain the social unrest that preceded the Civil War. Furthermore, the shrinking gap between returns from property and from labour in a context of social unrest, including threats to property, during the early I930s provides a potential explanation for the support lent by a non-negligible sector of the Spanish society to the military coup d'état that triggered the Civil War.

The outcome of the Civil War, Franco's long-lasting dictatorship (193975), encompassed two distinctive phases: autarchy and sluggish growth, in the first one; cautious liberalisation and fast economic progress, in the second. My estimates suggest that a dramatic increase in inequality, possibly a consequence of the Civil War, together with sluggish growth, resulted in stunning poverty, with one out of four Spaniards below the poverty line by the early I950s. A benevolent picture emerges, in turn, from the mid I950s onwards since, as income distribution became more egalitarian and growth accelerated, absolute poverty was practically suppressed by the mid i960s. Perhaps the successful transition to democracy in the last quarter of the twentieth century had its roots there. 


\section{Acknowledgements}

This article originated as a short-term research consultancy for a project on growth and poverty carried out at the Latin America \& the Caribbean Region Office of the World Bank. Humberto López and Luis Servén kindly allowed me access to their unpublished research. I have drawn extensively on the data base on labour returns Joan Rosés and I have constructed for our ongoing project on the proximate sources of long growth in Spain. Detailed comments and suggestions by Luis Bértola, Pedro Fraile Balbín, Francisco Goerlich, Alfonso Herranz-Loncán, Humberto López, Christian Morrison, Joan Rosés, Giovanni Vecchi, Jeff Williamson, and, especially, Branko Milanovic, are gratefully appreciated. I also thank Francisco Comín, Joan Esteban, Stefan Houpt, Santos Juliá, Matilde Mas, Jordi Palafox, Francisco Pérez, Mari Ángeles Pons, Fernando del Rey, Blanca Sánchez-Alonso, Javier Silvestre, James Simpson, Pedro Schwartz and Jan Luiten van Zanden, as well as participants at seminars at San Pablo-CEU and Valencia universities, the International Economic History Association Congress (Helsinki, August 2006) and I Congreso Latinoamericano de Historia Economica (Montevideo, December 2007). I have received financial support from the Spanish Ministry of Education and Sciences (Research Project SEC2002-01596 and 'Consolidating Economics') and Comunidad de Madrid (Projects CCGo6-UC 3 M/HUM-0872 and CCGo7$\mathrm{UC}_{3} \mathrm{M} / \mathrm{HUM}-3288$ ).

\section{References}

ALCAIDE INCHAUSTI, J. (I999). Distribución sectorial, factorial y personal de la renta. In J. L. García Delgado (ed.), España, Economía: ante el siglo XXI. Madrid: Espasa, pp. 457-8I.

AllEN, R. C. (2005). A pessimist's model of growth and inequality during the British Industrial Revolution. Nuffield College, University of Oxford (mimeo).

Alvaredo, F. and SAEZ, E. (2007). Income and wealth concentration in Spain in a historical and fiscal perspective. Paris School of Economics Paper 2007-39. Anuario Estadistico de Barcelona (I905). Barcelona: Ayuntamiento de Barcelona. Anuario Estadistico de España (several issues).

AtKinson, A. B. and BRANDOlini, A. (200I). Promise and pitfalls in the use of 'secondary' data-sets: income inequality in OECD countries as a case study. Fournal of Economic Literature 39, 3, pp. 77I-99.

Atkinson, A. B. and PiketTy, T. (2007). Top Incomes over the Twentieth Century. Oxford: Oxford University Press.

Baiges, J., Molinas, C. and Sebastian, M. (I987). La economía española 1964-1985. Datos, fuentes y análisis. Madrid: Instituto de Estudios Fiscales.

BANDRÉS, E. (1999). Gasto público y estructura del bienestar: el sistema de protección social. In J. L. García Delgado (ed.), España, Economía: ante el siglo XXI. Madrid: Espasa, pp. 63I-60.

BARCIELA, C. (2002). Guerra Civil y primer franquismo. In F. Comín, E. Llopis and M. Hernández (eds.), Historia Económica de España. Siglos $X-X X$. Barcelona: Crítica, pp. 33I-67.

BETRÁN, C. and PONS, M. A. (2004). Skilled and unskilled wage differentials and economic integration, I870-1930. European Review of Economic History 8, I, pp. 29-6o. 
BoIX, C. (2004). Spain: development, democracy and equity. IBRD World Development Report 2006 Background Paper.

BoURGUIGNON, F. (2002). The growth elasticity of poverty reduction: explaining heterogeneity across countries and time periods. Delta Working Papers 2002-3.

BourguignON, F. and MORRISSON, C. (2002), Inequality among world citizens: I820-I992. American Economic Review 92, 4, pp. 727-44.

Brenner, Y. S., KaElble, H. and Thomas, M. (eds.) (I99I). Income Distribution in Historical Perspective. Cambridge: Cambridge University Press.

BRINGAS GUTIÉRREZ, M. A. (2000). La productividad de los factores en la agricultura española (1752-1935). Madrid: Banco de España.

CABAllero, F. (I864). Memoria sobre el fomento de la población rural. Madrid: Imp. del Colegio de Sordo-mudos y de Ciegos.

CABRERA, M., and DEL REY Reguillo, F. (2002). El poder de los empresarios. Política y economía en la España contemporánea (1875-200o). Madrid: Taurus.

CAlvo-GonZÁleZ, O. (2007). American military interests and economic confidence in Spain under the Franco dictatorship. Fournal of Economic History 67, pp. 740-67.

CAMPS, E. (1995). La formación del mercado de trabajo industrial en la Cataluña del siglo XIX. Madrid: Ministerio de Trabajo y Seguridad Social.

CERDÁ, I. (I867). Teoría general de la urbanización y aplicación de sus principios y doctrinas a la reforma y ensanche de Barcelona. Barcelona.

ChastagnaReT, G. (2000). L'Espagne, puissance minière dans l'Europe du XIXe siècle. Madrid: Casa de Velásquez.

Clark, C. (1957). The Conditions of Economic Progress. 3rd edn. London: Macmillan.

Comín, F. (I996). Historia de la Hacienda pública, II España (I808-1995). Barcelona: Crítica.

Comín, F. (2002). El periodo de entreguerras (I9I9-I935). In F. Comín, E. Llopis and M. Hernández (eds.), Historia económica de España. Siglos $X-X X$, Barcelona: Crítica, pp. 285-329.

Comín, F. (2006). Reaching a political consensus for tax reform in Spain: the Moncloa pacts, joining the European Union and the best of the journey. Georgia State University, Andrew Young School of Policy Studies, International Studies Program Working Paper 06-oI.

Comín, F. (2007). The Spanish savings banks and the competitive cooperation model (1928-2002). Revista de Historia Económica/ Fournal of Iberian and Latin American Economic History 25, 2, pp. 199-229.

CRAFTS, N. (2000). Globalization and growth in the twentieth century. International Monetary Fund Working Paper 00/44.

CuAdrado Roura, J. R. (I999). Convergencia versus divergencia de las disparidades interregionales en España. In J. M. Maravall Herrero (ed.), Dimensiones de la desigualdad. Madrid: Fundación Argentaria/Visor, pp. 209-49.

DEININGER, K. and SQUIRE, L. (I996, updated). A new data set measuring income inequality. World Bank Economic Review Io, pp. 565-9I.

DEININGER, K. and SQUIRE, L. (I998). New ways of looking at old issues: inequality and growth. Fournal of Development Economics 57, pp. 257-85.

DomÉNECH, J. (2007). Working hours in the European Periphery. The length of the working day in Spain, I880-1920. Explorations in Economic History 44, pp. 469-86. 
DOMíngueZ, R. (2002). La riqueza de las regiones. Madrid: Alianza.

DUMKE, R. (I988). Income inequality and industrialization in Germany, I850-I9I3: images, trends and causes of historical inequality. Research in Economic History II, pp. I-47.

DUMKE, R. (I99I). Income inequality and industrialization in Germany, I850-I9I3: the Kuznets hypothesis re-visited. In Y. S. Brenner, H. Kaelble and M. Thomas (eds.), Income Distribution in Historical Perspective. Cambridge: Cambridge University Press, pp. I I7-48.

Encuesta de Estructura Salarial, Madrid: INE, several issues.

Encuesta de Salarios y de Coste Laboral, Madrid: INE, several issues.

ESCUDERO, A. (1998). Minería e industrialización de Vizcaya. Barcelona: Crítica.

EsTEBAN, J. and RAY, D. (I994). On the measurement of polarization. Econometrica 62, 819-52.

FLORA, P. (1983). State, Economy and Society in Western Europe, I815-1975. Frankfurt: Campus. 2 vols.

Francois, J. F. and RoJAs-Romagosa, H. (2005). The construction and interpretation of combined cross-section and time-series inequality datasets. World Bank Policy Research Working Paper 3748.

FUENTE, A. DE LA (2002). On the sources of convergence: a close look at Spanish regions. European Economic Review 46, 569-99.

FUNDACIÓN BBV (I999). Renta nacional de España y su distribución provincial: serie homogénea años I955 a I993 y avances I994 a I998. Bilbao: Fundación BBV.

Gimeno Ullastres, J. A. (I999). La incidencia redistributiva de las prestaciones públicas en especie: sanidad y educación. In J. M. Maravall Herrero (ed.), Dimensiones de la desigualdad. Madrid: Fundación Argentaria/Visor, pp. I5-67.

GoERLICH, F. J. and MAS, M. (200I). Inequality in Spain 1973-9I: contribution to a regional database. Review of Income and Wealth 47, 36I-78.

GoERLICH, F. J. and MAS, M. (2004). Distribución personal de la renta en España. 1973-200I. Papeles de Economía Española Ioo, 50-8.

GotTschalk, P. and SmeEding, T. M. (2000). Empirical evidence on income inequality in industrialized countries. In A. B. Atkinson and F. Bourguignon (eds.), Handbook of Income Distribution. Amsterdam: Elsevier, I, pp. 26I-307.

HoffmanN, W. G., Grumbach, F. and Hesse, H. (I965). Das Wachstum der deutschen Wirtschaft seit der Mitte des 19. Fahrunderts. Berlin: Springer.

HUBERMAN, M. (2005). Working hours of the world unite? New international evidence of worktime, I870-I9I3. Fournal of Economic History 64, 4, pp. 964-IOOI.

InstiTUTO DE REFORMAS SOCIALES (several issues), Memorias Generales de la Inspección de Trabajo. Madrid: Instituto de Reformas Sociales.

JAIN, S. (1975). Size Distribution of Income: A Compilation of Data. Washington, DC: The World Bank.

Kaelble, H. and Thomas, M. (I99I). Introduction. In Y. S. Brenner, H. Kaelble and M. Thomas (eds.), Income Distribution in Historical Perspective. Cambridge: Cambridge University Press, pp. I-56

KAKWANI, N. and PERNIA, E. (2000). What is pro-poor growth?. Asian Development Review I8, pp. I-I6.

KATZ, L. and AUTOR, D. (I999). Changes in the wage structure and earnings inequality. In O. C. Ashenfelter and D. Card (eds.), Handbook of Labor Economics, vol. 3A. Amsterdam: Elsevier, pp. I463-1555. 
KLASEN, S. (2004). In search of the holy grail: how to achieve pro-poor growth?. In B. Tungodden, N. Stern and I. Kolstad (eds.), Toward Pro-Poor Policies: Aid, Institutions, Globalization. New York: Oxford University Press, pp. 63-93.

KRAAY, A. (2006). When is growth pro-poor? Evidence from a panel of countries. Fournal of Development Economics 80, pp. 198-227.

KUZNETS, S. (1953). Shares of Upper Income Groups in Income and Savings. New York: NBER.

KuZNETS, S. (I955). Economic growth and income inequality. American Economic Review 45, I, pp. I-28.

KuZnets, S. (I966). Modern Economic Growth: Rate, Structure, and Spread. New Haven: Yale University Press.

LINDERT, P. H. (2000). Three centuries of inequality in Britain and America. In A. B. Atkinson and F. Bourguignon (eds.), Handbook of Income Distribution. Amsterdam: Elsevier, I, pp. I67-2 I6.

LóPEZ, J. H. (2004). Pro-poor-pro-growth: is there a trade off?. World Bank Policy Research Working Paper 3378.

LóPEZ, J. H. and SÉRVEN, L. (2006). A normal relationship? Poverty, growth, and inequality. World Bank Policy Research Working Paper 38I4.

LLONCH, M. (2004). Jornada, salarios y costes laborales en el sector textil catalán. Revista de Historia Industrial 26, pp. IOI-40.

MAdDISON, A. (2003). The World Economy: Historical Statistics. Paris: OECD Development Centre.

MAluquer De Motes Bernet, J. and LlonCH, M. (2005). Trabajo y relaciones laborales. In A. Carreras and X. Tafunell (eds.), Estadísticas históricas de España. Bilbao: Fundación BBVA, III, pp. II55-245.

MARTIN, B. (1990). The Agony of Modernization. Labor and Industrialization in Spain. Ithaca, NY: ILR Press.

MARTÍN ACEÑA, P. and PONS, M. A. (2005). Sistema monetario y financiero. In A. Carreras and X. Tafunell (eds.), Estadísticas históricas de España. Madrid: Fundación BBVA, II, pp. 647-706.

Matthews, R. C. O., Feinstein, C. H. and Odling-Smee, J. C. (I982). British Economic Growth I856-1973. Oxford: Clarendon Press.

Milanovic, B. (2005). Worlds Apart: Measuring International and Global Inequality. Princeton: Princeton University Press.

Milanovic, B., Lindert, P. H. and Williamson, J. G. (2007). Measuring Ancient inequality. NBER Working Paper Series 13550 www.nber.org/papers/wI3550

MINISTERIO DE TRABAJO (I93I). Estadística de salarios y jornadas de trabajo: I9I4-1930. Resultados globales en toda la Nación. Madrid: Ministerio de Trabajo.

Ministerio DE TRABAJO (I965-79). Salarios, Madrid: Ministerio de Trabajo.

MORRISSON, C. (2000). Historical perspectives on income distribution: the case of Europe. In A. B. Atkinson and F. Bourguignon (eds.), Handbook of Income Distribution. Amsterdam: Elsevier, I, pp. 217-60.

MORRISSON, C. and SNYDER, W. (2000). The income inequality of France in historical perspective. European Review of Economic History 4, pp. 59-83.

NúÑEZ, C. E. (2005). Educación. In A. Carreras and X. Tafunell (eds.), Estadísticas históricas de España. Madrid: Fundación BBVA, I, pp. I55-244. OECD (2006). The Labour Force Statistics Database. Paris: OECD.

PAN-MonTOJO, J. (ed.) (2007). Los inspectores de Hacienda en España: una mirada histórica. Madrid, Centro de Estudios Financieros-APIFE. 
PAyne, S. G. (1993). Spain's First Democracy: The Second Republic, 1931-I936. Maddison: University of Wisconsin Press.

PÉrez CAstroviejo, P. M. (I992). Clase obrera y niveles de vida en las primeras fases de la industrialización vizcaina. Madrid: Ministerio de Trabajo y Seguridad Social.

PÉREZ Ledesma, M., I990. Estabilidad y conflicto social. España, de los iberos al I4-D. Madrid: Nerea.

PigOU, A. C. (1920). The Economics of Welfare. London: Macmillan.

PIKETTY, T. (2003). Income inequality in France, I90I-I998. Fournal of Political Economy III, 5, pp. I004-42.

PIKeTTy, T. and SAEZ, E. (2006). The evolution of top incomes: a historical and international perspective. American Economic Review. Papers and Proceedings. 96, 2, pp. 200-5.

PRADOs DE LA Escosura, L. (2003). El progreso económico de España, I850-2000. Madrid: Fundación BBVA.

PRADOS DE LA EsCOSURA, L. (2007a). Growth and structural change in Spain, I850-2000: a European perspective. Revista de Historia Económica/ Fournal of Iberian and Latin American Economic History 25, I, pp. I47-8I.

PRADOS DE LA EsCOSURA, L. (2007b). Inequality and poverty in Latin America: a long-run exploration. In T. J. Hatton, K. H. O'Rourke and A. M. Taylor (eds.), New Comparative Economic History. Cambridge, MA: MIT Press, pp. 29I-3I5.

PRADOS DE LA EsCOSURA, L. (2007c). La posición internacional de la economía española, I850-I935: una estimación preliminar de la balanza de pagos. Universidad Carlos III (mimeo).

Prados de la Escosura, L. and SANZ, J. C. (I996). Growth and macroeconomic performance in Spain (I939-I993). In N. Crafts and G. Toniolo (eds.), Economic Growth in Europe since 1945. Cambridge: Cambridge University Press/CEPR, pp. 355-87.

PRAdos DE LA Escosura, L. and Rosés, J. R. (2003). National income accounts: wages and labor. In J. Mokyr (ed.), Oxford Encyclopedia of Economic History. New York: Oxford University Press, pp. 48-52.

PRADOS DE LA Escosura, L. and RosÉs, J. R. (2007). The sources of long-run growth in Spain, I850-2000. CEPR Discussion Paper 6I89.

QUIROGA, G. and COLL, S. (2000). Income distribution in the mirror of height differences: the case of Spain I895-1950. Fournal of Income Distribution 9, I07-31.

RAVALliON, M. (I997). Can high inequality development countries escape absolute poverty?. Economics Letters 56, $5 \mathrm{I}-7$.

RAVAllion, M. (2004). Pro-poor growth: a primer. World Bank Policy Research Working Paper no. 3242.

Ravallion, M., CHEN, S. (2003). Measuring pro-poor growth. Economics Letters 78, pp. 93-9.

ReHer, D. S. and BAllesteros, E. (I993). Precios y salarios en Castilla la Nueva: la construcción de un índice de salarios reales, I509-I99I. Revista de Historia Económica II, I, pp. IOI-5I.

Río OTERo, C. DEL, Ruiz-CAstillo UCElay, J. (I999). El enfoque de la dominancia en el análisis de la pobreza. In J. M. Maravall Herrero (ed.), Dimensiones de la desigualdad. Madrid: Fundación Argentaria/Visor, pp. 429-60. RoDRIK, D. (I997). Trade, social insurance, and the limits to globalization. NBER Working Paper 5905. 
RosÉs, J. R. and SÁNCHEZ-AlONSO, B. (2004). Regional wage convergence in Spain, I850-I930. Explorations in Economic History 4I, pp. 404-25.

Rossi, N., Toniolo, G. and VECCHI, G. (200I). Is the Kuznets curve still alive? Evidence from Italian household budgets, I88I-I96I. Fournal of Economic History 6I, 4, pp. 904-25.

Ruiz-Castillo Ucelay, J. and SAstre García, M. (I999). Desigualdad y bienestar en España en términos reales: I973-74, I980-8I y I990-9I. In J. M. Maravall Herrero (ed.), Dimensiones de la desigualdad. Madrid: Fundación Argentaria/Visor, pp. 345-66.

SÁNCHEZ-AlONSO, B. (2000). European emigration in the late nineteenth century: the paradoxical case of Spain. Economic History Review 53, pp. 309-30.

SÁNCHEZ-AlONSO, B. (2007). The other Europeans: immigration into Latin America and the international labour market, I870-1930. Revista de Historia Económica/fournal of Iberian and Latin American Economic History 25, 3, 2007, pp. $395-426$.

SiLVESTRE, J. (2003). Migraciones interiores y mercado de trabajo en España, I877-I936. PhD Dissertation, Universidad de Zaragoza.

SILVESTRE, J. (2005). Internal migrations in Spain, I877-I930. European Review of Economic History 9, 233-65.

SOLER, R. (I997). La evolución del salario en una empresa textil algodonera. La fábrica de La Rambla de Vilanova i la Geltrú (I89I-1925). Revista de Historia Económica 15, 2, pp. 399-4II.

SOTO CARMONA, A. (I989). El trabajo industrial en la España contemporánea: (1874-1936). Barcelona: Anthropos.

STOlPer, W. and SAMUelson, P. (I94I). Protection and real wages. Review of Economic Studies 9, 58-73.

SZÉKELY, M. (200I). The I990s in Latin America: another decade of persistent inequality, but with somewhat lower poverty. Inter-American Development Bank Working Paper Series 454.

TAFUnElL, X. (2005). Construcción y vivienda. In A. Carreras and X. Tafunell (eds.), Estadísticas históricas de España. Madrid: Fundación BBVA, I, pp. 455-99.

US DEPARTMENT OF LABOR (I900). Fifteenth Annual Report of the Commissioner of Labor: Wages in Commercial Countries. Washington, DC: GPO.

VILAR, M. (2004). La ruptura posbélica a través del comportamiento de los salarios industriales: nueva evidencia cuantitativa (I908-I963). Revista de Historia Industrial 45, pp. 8I-I26.

WIDER [World Institute for Development Economics Research] (2005). World Income Database. Helsinki: UNO/WIDER/UNDP.

Williamson, J. G. (I982). The structure of pay in Britain, I7IO-I9II. Research in Economic History 7, pp. I-54.

Williamson, J. G. (I985). Did British Capitalism Breed Inequality?. London: Allen and Unwin.

Williamson, J. G. (I997). Globalization and inequality, past and present. World Bank Research Observer 12, 2, pp. I 7 7-35.

Williamson, J. G. (2002). Land, labor, and globalization in the Third World, I870-I940. Fournal of Economic History 62, pp. 55-85.

Williamson, J. G. and Lindert, P. H. (I980). American Inequality: $A$ Macroeconomic History. New York: Academic Press. 


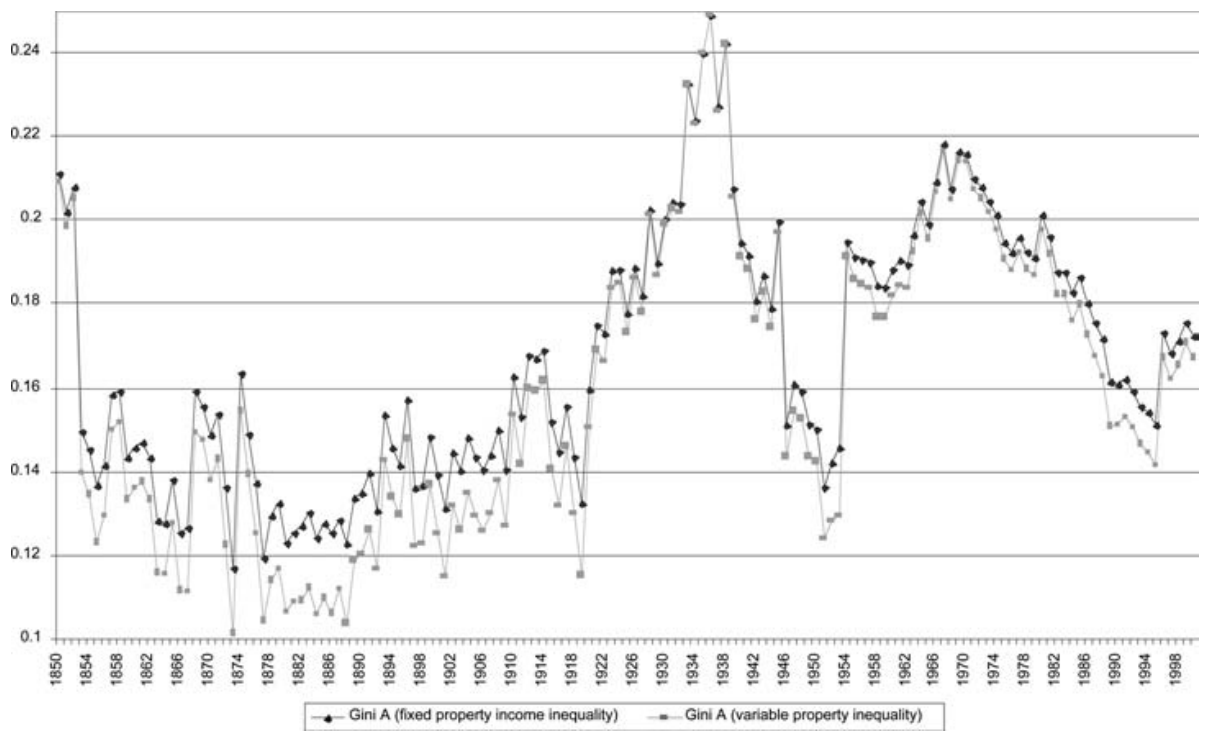

Figure A-I. Gini A: alternative estimates with fixed and variable property inequality

\section{Appendix}

The following inequality indicators have been computed:

$y / w u s$, the ratio of nominal GDP per hour to nominal unskilled wage per hour.

$y / w$, the ratio of nominal GDP per hour to nominal average wage per hour.

Gini $=\sum G_{i} n_{i} \pi_{i}+\sum\left(\left(y_{p}-y_{l}\right) / y_{l}\right) \pi_{l} n_{p}+L$, or Gini $A+$ Gini $B+L$, where $G_{i}$ is the Gini coefficient for labour $(l)$ and property $(p) ; n_{i}$ and $\pi_{i}$, the shares of each group (proprietors $(p)$ and workers $(l)$ in population and in national income, respectively; $y_{p}$ and $y_{l}$, the mean income of property owners and workers, respectively.

\section{Sources and computation procedures}

Nominal GDP derives from Prados de la Escosura (2003).

Nominal unskilled wage corresponds to that for agriculture for the period 1850-I954; from I954 onwards, it is the weighted average unskilled wage rate per hour (weights are the number of hours worked in each branch of economic activity).

Nominal average wage is the nominal weighted average wage rate per hour (weights are the number of hours worked in each of branch of economic activity).

Wage and employment series

Average wages and employment (hours worked) have been computed across main branches of economic activity (I9 up to I900, 22 for the period I900-54, and 24 since I954): Agriculture and Forestry, Fishing (up to I900, together with agriculture and forestry), Energy and Water, Metal Mining and Processing, Non-Metal Mining, Chemical, Metal Produce and Machinery, Transport Equipment, Food, Drink 


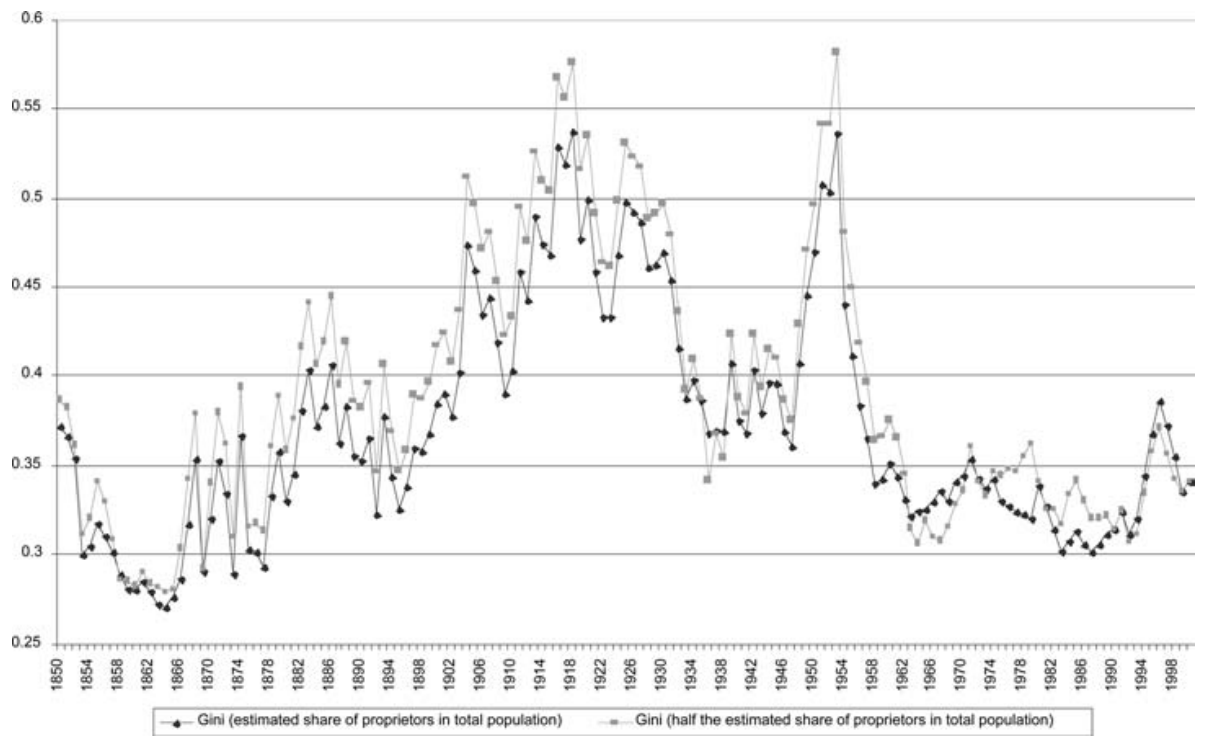

Figure A-2. Alternative Gini computed with the estimated share of proprietors in population and with a half of it

and Tobacco, Textiles, Leather and Shoemaking, Paper and Printing, Wood and Furniture, Rubber, Plastics and Miscellaneous Manufacturing (prior to 1900, together with wood and furniture), Building and Engineering, Repairs, Commerce, Real Estate (the last three together up to 1954), Banking and Insurance (together with repairs, commerce and real estate up to 1900), Hotels and Restaurants, Transport and Communications, Education and Health (private), Miscellaneous Market Services, Domestic Service and Government. From I954 onwards, four occupational categories were distinguished in each of the 24 branches of economic activity (unskilled, skilled operatives, technicians and managers). As regards selfemployed workers, it was assumed, following the principle of opportunity cost, that their labour cost was equal to that of the average worker in their industry and assigned the same wage.

\section{Wages}

The quality and availability of wage data necessary to construct these estimates vary enormously through time. Different periods can be distinguished:

1850-1908. Agricultural wages come from Bringas (2000). Wages in construction and services from Reher and E. Ballesteros (1993) were re-scaled to the national levels provided by Rosés and Sánchez-Alonso (2004). Wages for mining are from Chastagneret (2000) and Escudero (1998). Levels of manufacturing wages in all industry and services sectors at different dates (1850, I880, 1905) were obtained, respectively, from Cerdá (I867), the US Department of Labor, and Anuario Estadistico de Barcelona. Benchmark wage levels were interpolated with Fisher indices constructed with yearly data from Camps (1995), Llonch (2004), Soler (1997), for consumer industries, and Escudero (I998) and Pérez Castroviejo (1992), for the rest. 


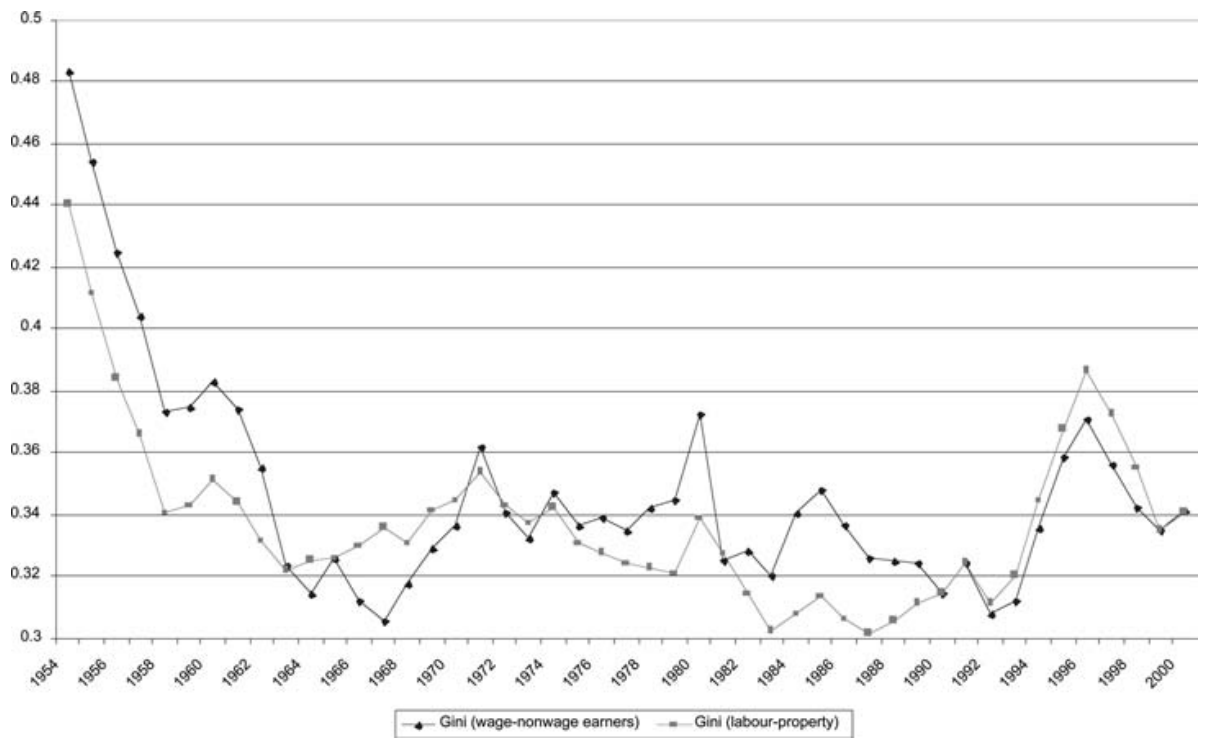

Figure A-3. Alternative Gini distinguishing between wage and nonwage earners and between labour and property

1908-20. The detailed wage enquires conducted by the Instituto de Reformas Sociales with information by gender on minimum, maximum and average wages for twenty branches of industry (kindly provided by Javier Silvestre) were used. Wages in agriculture and services were taken from Bringas (2000) and Reher and Ballesteros (I993), respectively.

1920-54. Wage levels from a detailed survey for I9I4, I920, 1925 and 1930 (Ministerio de Trabajo (I93I) were interpolated with wage variation rates provided in Anuario Estadístico de España (AEE) (only nine occupations up to 1925, fifteen thereafter) to derive nominal wage series, classified by industry, for the period I92036. During the early years of General Franco's dictatorship wages and salaries were severely regulated and included in-kind and extra-payments not comprised in the wage data from earlier publications. Wage levels for 1930 and 1955 were spliced with a Fisher index of wage yearly variations constructed from data in $A E E$ and Vilar (2004) to obtain yearly wage series.

1954-2000. Labour costs by sectors of economic activity from Fundación BBV (1999) were used. These do not, however, provide a breakdown by occupational categories that had to be obtained, in turn, from the official enquiries on wage, labour costs and wage structure (Salarios, Encuesta de Salarios y de Coste Laboral and Encuesta de Estructura Salarial), and which were later re-scaled to match aggregate figures in Fundación BBV (1999) statistics.

\section{Employment (hours worked)}

1850-1954. Economically active population (EAP) is only available at benchmark years with no regard to involuntary unemployment, while female EAP in agriculture 
is inconsistent over time. In order to derive consistent figures over time for EAP in agriculture, the census figures for female population were excluded, while it was assumed that female labour represented a stable proportion of male labour force. Yearly EAP figures were obtained through log-linear interpolation of census benchmark observations. Employment figures for each major sector of economic activity were then derived by adjusting yearly EAP series for the economic cycle.

Next, the number of workers was transformed into days and, then, hours worked per year. On the basis of available evidence it was assumed that each full-time worker was employed 270 days per annum in industry and services, after deducting Sundays and religious holidays plus an allowance for illness. In agriculture, a lower figure for the working days per occupied person has often been suggested. Thus, I assumed that female labour represented a stable proportion of male labour force in this sector and the number of days assigned to each male worker was raised to 270 days per year per occupied person in the countryside, distributed between agriculture (240 days) and services (30 days). As regards the number of daily hours worked per occupied by sector, the following sources were used. For mid-nineteenth-century agriculture, Caballero (I864) pointed to Io hours per day while a similar average figure, 9.7 hours, was found for the mid I950s. I accepted Io hours per day for I850-I9II and interpolated these two figures for the period I9I2-35, while maintaining 9.7 hours for the period 1936-54. For industry and services, Huberman's (2005) figures for $1870-$ 99 were accepted and interpolated to derive annual hours worked, while the number of hours worked in 1870 was accepted for I850-69. Domenech's (2007) estimates for different industries and services in I9I0 were adopted for 1900-IO, while Silvestre's (2003) annual computations for industry were used for I9II-I9. Soto Carmona (1989) provides some construction and services figures for the interwar years. The next period for which quantitative evidence on hours worked was available was the early I950s. The number of hours per worker was often close to that of I9I9, so I accepted the number of working hours per occupied person in 1954 for the years I936-53, and interpolated the figures for I9I9 and 1936.

1954-2000. Labour force data come from the MOISSES base for the period 195463, from Baiges et al. (1987) for 1964-80, and from the national accounts for 1980-2000. The distribution of overall labour force across the different industries was based on Fundación BBV's (1999) studies, and then workers in each industry were distributed into four occupational categories (unskilled and skilled operatives, technicians and managers) with information provided by Instituto Nacional de Estadística. Hours per economically active population for the I950s come from Sanchis (private communication), Maluquer de Motes and Llonch (2005) for 1958 63. Ministerio de Trabajo (1965-79) for 1964-78, and OECD (2006) from 1979 onwards.

\section{Gini for nominal wage yearly earnings}

Only the Gini coefficient for labour (wages) has been computed. Assumptions about the hypothetical value of the Gini coefficient for property and its evolution are offered in the main text. Gini coefficients have been computed for average wage earnings across the main branches of economic activity (for 19, 22 and 24 


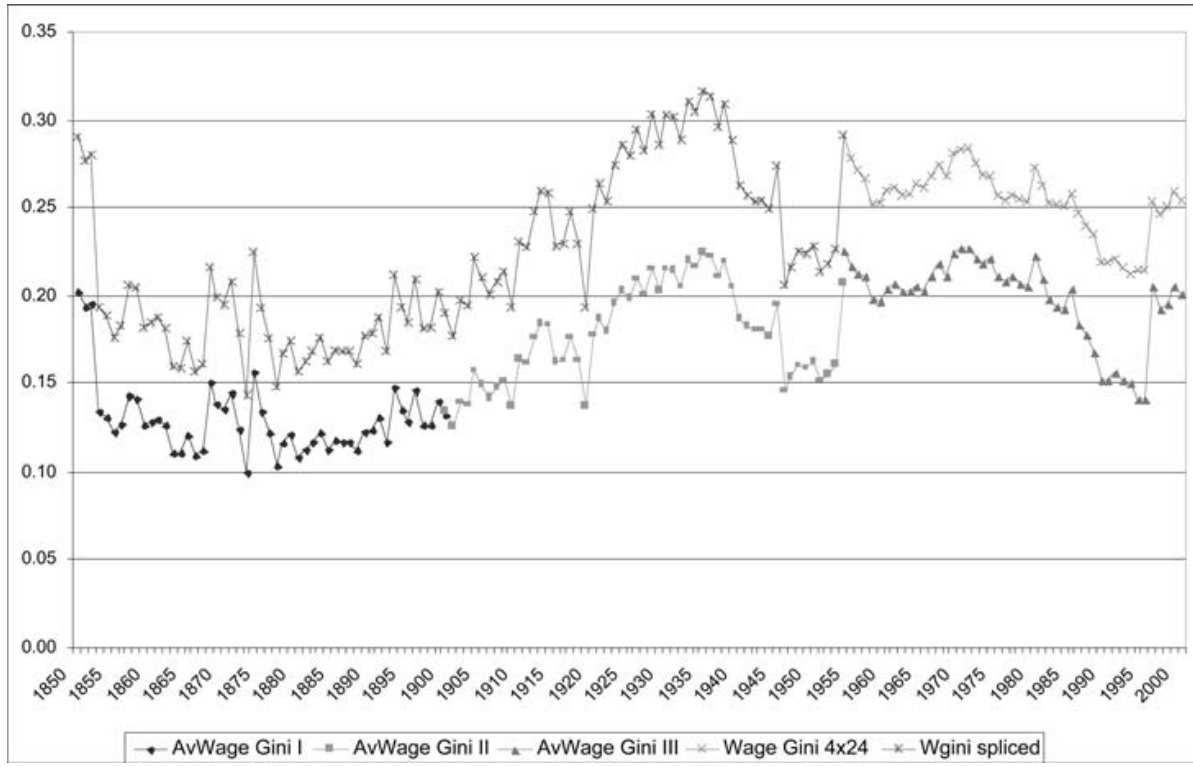

Figure A-4. Wage Gini: alternative estimates

sectors (AvGini I, II and III, respectively) and, for 1954-2000, also across the four occupational categories within each of the 24 industries considered (unskilled and skilled operatives, technicians and managers) (Wage Gini $4 \times 24$ ). As these alternative inequality measures show very close results (Figure A-4) I spliced them into a single one using their ratios in the overlapping years (Wgini spliced). Thus, $\mathrm{G}_{\mathrm{i}}{ }^{\prime}=\left(\mathrm{G}_{\mathrm{o}}{ }_{\mathrm{o}} / \mathrm{G}_{\mathrm{o}}\right)$ $G_{i}$, where $G_{i}^{\prime}$ represents the closer Gini series to the present (and the one with wider coverage of industries) and $\mathrm{G}_{\mathrm{i}}$, the more remote (and with lower coverage) one, while $\mathrm{G}_{\mathrm{o}}{ }_{\mathrm{o}} / \mathrm{G}_{\mathrm{o}}$ represents their ratio in the year they overlap.

Deriving the shares in national income $\left(\pi_{i}\right)$ of proprietors $(p)$ and workers (l)

1850-1954. Labour returns were directly estimated by multiplying the total hours worked per occupied person and year by wage rates per hour in each industry (see above). The share of labour in national income resulted from dividing labour returns by GDP at factor costs.

1954-2000. Factor shares were derived from labour and property compensation provided by the different sets of national accounts previously spliced. To measure labour income correctly it is crucial to establish which proportion of the income of proprietors, unpaid family workers, self-employed and retired workers represent returns to labour. Entrepreneurs and self-employed workers were attributed a labour income per head equal to the average compensation of employees in their corresponding industry. Dividing the compensation of total labour (including the self-employed) by GDP at factor costs we arrive at the labour share in national income. 
The share of property was obtained as a residual after deducting labour returns from GDP at factor cost. Then, $y_{p}$ and $y_{l}$, the mean income of property owners and workers, respectively were derived by multiplying $\pi_{p}$ and $\pi_{l}$ by nominal per capita GDP.

Deriving the shares in population $\left(n_{i}\right)$ shares of each group (proprietors ( $p$ ) and workers (l)): see the main text

More details about the sources and procedures used are provided in Prados de la Escosura and Rosés (2007). 